ENITEN AIKUISOPISKELIJOITA

ON MONIALAISISSA

MAAKUNTAYLIOPISTOISSA.

\section{Pitkä tie yliopistoon \\ Toisen mahdollisuuden käyttäjät}

\author{
$y$ \\ Aikuisena yliopistoon hakeutumisen syitä ovat muun muassa \\ halu edetä uralla, ammatin ja alan vaihto, opiskelumotivaation \\ löytyminen ja uusien haasteiden etsiminen. Miten toisen \\ mahdollisuuden käyttäjät eroavat muista korkeakouluopiskelijoista
}

taustoiltaan, motiiveiltaan ja koulutuspoluiltaan?

\section{y}

SOMALAISESSA KOULUTUSPOLIITTISESSA

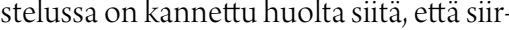
mä toisen asteen opinnoista korkeakoulutukseen on hidas. Vuonna 2015 alle 30 prosenttia uusista ylioppilaista jatkoi suoraan yliopistoon tai ammattikorkeakouluun. Yliopisto-opinnot aloitetaan Suomessa vanhempana kuin useimmissa muissa Euroopan unionin maissa. Vuonna 2014 uusien yliopisto-opiskelijoiden iän mediaani oli Suomessa noin 21 vuotta (OKM 2017).

Opetus- ja kulttuuriministeriö onkin linjannut yhdessä korkeakoulujen kanssa, että todistusvalin- toihin perustuvaa opiskelijavalintaa lisätään, ja pitkää valmentautumista edellyttävistä pääsykokeista luovutaan. Tavoite on, että samalla kun hakeminen helpottuu, välivuodet vähenevät ja tarve osallistua valmennuskursseille poistuu. (OKM 2016.) Opiskelijavalintauudistus tähtää siten siihen, että yliopistoon haetaan suoraan toisen asteen koulutuksen jälkeen. Samalla aikuisena hakevien määrä vähenee.

Se, minkä ikäiset yliopisto-opiskelijat määritellään aikuisopiskelijoiksi, vaihtelee eri tutkimuksissa. Suomalaisissa tutkimuksissa aikuisuuden ikärajana on tyypillisesti 25 (Rinne, Haltia, Nori \& Jauhiainen 2008 ) tai 30 vuotta (Moore 2000 \& 2003). Vuonna 2017 yliopistojen uusista opiskelijoista 25 vuotta täyttäneitä oli noin 27 prosenttia, ja 30-vuotiaita ja sitä vanhempia noin 14 prosenttia (Vipunen 2017). Aikuisopiskelijoiden osuus yliopistoissa on siis suhteellisen suuri. Vaikka naiset osallistuvat miehiä ahkerammin aikuiskoulutukseen, aikuiset yliopisto-opiskelijat eivät ole sen naisvaltaisempi ryhmä kuin nuoretkaan: naisten osuus sekä nuorissa että aikuisissa opiskelijoissa on noin 60 prosenttia (Rinne ym. 2008; ks. myös O'Shea 2014).

Ikää merkittävämpi aikuisuuden määritelmä on sidoksissa elämäntilanteeseen. Aikuiset opiskelijat ovat usein perheellisiä, ja heillä on pitkä kokemus työelämästä. Useimmilla on jokin ammatillinen koulutus takanaan, joillakin jopa useita tutkintoja. Heissä on myös niitä, jotka ovat suorittaneet aiemmin korkeakoulututkinnon, huomanneet valinneensa väärän lan ja haluavat suorittaa toisen tutkinnon toiselta alalta tai toisesta korkeakoulusta. (Moore 2003.)

Aikuisiällä yliopistoon hakeutuneissa on keskimääräistä enemmän ei-ylioppilaita, jotka ovat hankkineet hakukelpoisuuden suorittamalla ammatillisen tutkinnon ylioppilastutkinnon sijaan. Ammatillisen tutkinnon jälkeen pyritään kuitenkin harvoin suoraan yliopistoon: useimmat koukkaavat ammattikorkeakoulun kautta ja hakeutuvat vasta sieltä valmistuttuaan yliopistoon. (Haltia, Jauhiainen \& IsopahkalaBouret 2017.)

Aikuiset hakeutuvat yliopistoon opiskelemaan usein muun muassa terveys- ja hoitotieteitä, kasvatustieteitä, yhteiskuntatieteitä ja teologiaa. (Moore 2000; Halttunen 2007; Rinne ym. 2008.) Vähiten aikuisia on oikeustieteessä, lääke- ja hammaslääketieteessä, eläinlääketieteessä sekä humanistisilla teknillisillä ja luonnontieteellisillä aloilla. Yliopistot eroavat sen suhteen, kuinka paljon niissä opiskelee aikuisopiskelijoita: eniten heitä on monialaisissa maakuntayliopistoissa, kuten Itä-Suomen ja Lapin yliopistoissa. (Rinne ym. 2008.

Aikuisen identiteetti on muodostunut aiempien opiskelu- ja työkokemusten kautta, minkä vuoksi yliopisto-opiskelijan identiteetin omaksuminen voi olla vaikeaa (Askham 2008). Epävarmuuden kokemukset yliopisto-opinnoissa päräämisestä ovat tavallisia, koska aiemmista opinnoista on usein kulunut aikaa. Aikuiset yliopisto-opiskelijat saattavat tuntea myös "toiseutta" (Read, Archer \& Leathwood 2003; O'Boyle 2014), eli he kokevat olevansa erilaisia kuin tyypilliset yliopisto-opiskelijat, jotka ovat jatkaneet opintojaan pian lukiosta pääsyn jälkeen. Koska keskimääräistä vanhempana yliopistoon hakeutuneet ovat varsin usein sukunsa ensimmäisiä yliopistoopiskelijoita, akateemisen maailman olemisen tavat ja kieli voivat tuntua heistä vierailta (Käyhkö 2014)

Sosiaalipsykologi Jenny Mercerin (2007) mukaan erityisesti epätyypilliset yliopisto-opiskelijat, joihin aikuiset opiskelijatkin lukeutuvat, suhtautuvat tunnepitoisemmin ja henkilökohtaisemmin opiskeluun kuin niin sanotut tyypilliset yliopisto-opiskelijat. Opiskelu yliopistossa on paljon muutakin kuin akateemisten tietojen ja taitojen hankkimista ja uramahdollisuuksien parantamista. Opiskelun avulla aikuiset rakentavat identiteettiään ja kirjoittavat elämäkertaansa uudelleen. Mercer kuvaa tätä prosessia termillä re-negotiation of the self,' 'minuuden uudelleenneuvottelu' $(2007,21)$. Opiskelulla on suora vaikutus identiteettiin, siihen, millaisena aikuinen näkee itsensä ja suhteensa ympäröivään maailmaan.

YLIOPISTOON HAKEUTUMINEN, KOTITAUSTA JA ELÄMÄN KÄÄNNEKOHDAT

Tutkimusten mukaan (esim. Moisio 2017) kotitausta on yhteydessä opintojen aloitusikään. Ne yliopistoopiskelijat, joiden vanhemmilla ei ole korkeakoulututkintoa, aloittavat opintonsa jopa neljä vuotta vanhempina kuin korkeakoulutetuista perheistä tulevat. Tätä on selitetty muun muassa sillä, että nuorella ei ole kotonaan kouluttautumisen mallia, eivätkä vähän kouluja käyneet vanhemmat pysty opastamaan lapsiaan koulutusvalinnoissa samaan tapaan kuin korkeakoulutetut vanhemmat. 


\section{MYÖHÄISMODERNEISSA}

YHTEISKUNNISSA

YKSILÖIDEN AJATELLAAN

RAKENTAVAN ITSE OMAT

EL ÄM ̈̈KERTANSA.

Koulutuksen periytyvyyttä ja kulttuurista uusintamista painottavien teorioiden mukaan työläisperheessä kasvaneet ovat jo lähtökohtaisesti heikommassa asemassa kuin korkeasti koulutettujen vanhempien lapset, jotka ovat kodin perintönä saaneet koulumaailman odotuksiin ja arvoihin nähden oikeanlaista kulttuurista pääomaa (Bourdieu 1986). Matalasti koulutetun perheen jälkeläiset arvioivat lisäksi helposti pitkäkestoisen koulutuksen liian suureksi taloudelliseksi riskiksi (Reay 2003), varsinkin, jos työllistyminen valmistumisen jälkeen on epävarmaa (Archer \& Hutchings 2000)

Brittiläisten kasvatustieteilijöiden Andrew Marksin, Eileen Turnerin ja Mike Osbornen (2003) mukaan yliopistoon hakeutumista viivästyttävät muun muassa aiemmat huonot koulukokemukset, tuen ja rohkaisun puute sekä haluttomuus rikkoa omassa yhteisössä vallitsevia normeja. Työläisperheissä saatetaan esimerkiksi kokea, että pitkä koulutus on ajanhukkaa, ja että taloudellisesti kannattavampaa on hakeutua suoraan työelämään lyhyen ammatillisen koulutuksen kautta.

Kyvyistään ja tulevaisuudestaan epävarmat työläistaustaiset valikoivat itsensä usein ulos jo potentiaalisten hakijoiden joukosta; yliopistokoulutus ei kuulu heidän maailmaansa vaan rajautuu kokonaan toiminnan horisontin ulkopuolelle (Hodkinson \& Sparkes 1997). Sen sijaan erityisesti suoraan ylioppilaskirjoitusten jälkeen yliopistoon pyrkivät nuoret tulevat usein perheistä, jotka pystyvät tukemaan jälkeläisiään taloudellisesti ja henkisesti ja joissa korkea koulutus nähdään miltei itsestäänselvyytenä. (Nori 2011.)

Länsimaisissa myöhäismoderneissa yhteiskunnissa yksilöiden ajatellaan kykenevän rakentamaan itse omat elämäkertansa. Valintojen odotetaan yhtältta olevan henkilökohtaisia, yksilöllisiä ja erityisiä, toisaata perheen ja lähipiirin hyväksyntää pidetään tärkeänä. Tämä on omiaan aiheuttamaan ahdistusta ja epävarmuutta. Koulutusvalintoja ei voi tarkastella yksittäisenä tilanteena vaan monimutkaisena prosessina, ja valinnat tehdään aina tietyssä kulttuurisessa ja sosiaalisessa kontekstissa. (Holmegaard, Ulriksen \& Madsen 2014. .

Oman identiteetin ja elämäkerran rakentaminen ei kuitenkaan pääty nuoruusiässä, vaan yksilö työstävät omia valintojaan koko eliniän. Monet arvioivat esimerkiksi nuoruusiässä tehtyjä valintoja uudelleen aikuisena. Aikuisiässä kouluttautumisesta onkin perinteisesti puhuttu 'toisena mahdollisuutena' silloin, jos sen avulla kompensoidaan lapsuus- ja nuoruusiässä epäonnistunutta koulutusta. 'Toisella mahdollisuudella' voidaan myös viitata laajemmin myöhäismoderniin elämänkulkuun, joka ei etene enää lineaarisesti ennalta määrättyjen vaiheiden läpi, koska aikuisiässäkin on mahdollisuus "uusiin alkuihin” esimerkiksi työn, koulutuksen tai perhe-elämän alueilla. (Ks. Moore 2003, 96.)

Tutkimuksissa on myös todettu, että erityisesti elämän käännekohdat (turning points) (ks. O'Shea 2014) kuten perheen perustaminen, avioero ja työttömyys, voivat vaikuttaa siihen, että omia valintoja kouluttautumisen ja uran suhteen pohditaan uudestaan.

\section{TUTKIMUSAINEISTOT JA MENETELMÄT}

Tarkastelemme yliopistossa aikuisina opiskelevien profiilia ja koulutuspolkuja (ks. esim. Jenkins 2017) Kysymme, miten yliopiston aikuisopiskelijat poikkeavat muista opiskelijoista ja mikä on saanut heidä hakeutumaan yliopisto-opintoihin vasta aikuisiässä.

Tutkimuskysymyksiin vastaamme kahden erilaisen ja toisiaan täydentävän aineiston avulla. Tilastokeskuksen kokoama henkilörekisteripohjainen tilastoaineisto käsittää 50 prosentin satunnaisotoksen $(N=23$ 826) Suomessa vuonna 2014 maisterintutkintoa suorittaneista opiskelijoista. Vuonna 2014 yliopistoissa perustutkinto-opiskelijoita oli vajaat 140 000, joista kaksi kolmannesta suoritti kandidaatin ja kolmannes maisterin tutkintoa (Vipunen 2018) Toisena aineistona käytämme Turun yliopistoss
LÄHITARKASTELUUN

VALITSIMME

NELJ $\ddot{A}$ EDUSTAVAA

KOULUTUSEL $\ddot{A M} \ddot{K}$ KRTAA.

vuosina 2011-2015 aikuiskasvatustiedettä pää- ta sivuaineenaan opiskelleiden aikuisten $(\mathrm{N}=42)$ kirjoittamia koulutuselämäkertoja. Tilastoaineiston muuttujat kuvaavat opiskeluun, perhe- ja elämäntilanteeseen sekä kotitaustaan liittyviä asioita. Opiskeluun liittyviä muuttujia ovat tieteenala, tut kinto, opintojen aloitusvuosi ja läsnäolo. Perhe- ja elämäntilannetta kuvaavia muuttujia ovat ikä, sukupuoli, siviilisääty, lasten lukumäärä, asuinpaikka, aiempi koulutus, ammatillinen asema ja tulot. Kotitaustaa koskevia muuttujia ovat puolestaan vanhempien koulutus, sosioekonominen asema ammatti ja tulotaso.

Rekisteriaineiston analysoinnissa olemme hyödyntäneet ryhmittely- eli klusterianalyysiä ja ristiintaulukointia. Klusterianalyysi on monimuuttujamenetelmä, jossa havainnot ryhmitellään niin että ryhmät ovat sisäisesti mahdollisimman homogeenisiä, mutta samaan aikaan ryhmien väliset erot ovat mahdollisimman suuret (Bahr, Bielby \& House 2011, 68; Nummenmaa 2004, 363, 367). Klusterianalyysissa tutkijan omilla valinnoilla ja tulkinnoilla on suuri merkitys (Nummenmaa 2004,367). Sen avulla tutkija pääsee tutustumaan aineistoon ja tutkimusaiheeseen, mutta pidemmälle meneviä päätelmiä tulee tehdä varoen. Siks klusterianalyysiin kannattaa yhdistää muita analyysimenetelmiä.

Klusterianalyysityyppejä on kahdenlaisia: hierarkkinen klusterianalyysi (Hierarchical Cluster Analysis) ja k-keskiarvoklusterianalyysi (K-Mean Cluster Analysis), jota käytämme siksi, että se sopii suurten aineistojen analysointiin. Analyysi edellyttää, että muuttujat ovat välimatka-asteikollisia.
Valitsimme analyysiin mukaan seuraavat muuttujat: ikä, lasten lukumäää, opintojen kesto, korkeimman tutkinnon suorittamisesta kulunut aika, vuositulot, äidin koulutusaste, äidin vuositulot, isän koulutusaste ja isän vuositulot.

Koulutusaste on tosiasiassa järjestysasteikollinen muuttuja, mutta käsittelemme sitä välimatka-asteikollisen muuttujan tavoin: ajattelemme, että arvojen järjestys ja etäisyydet ovat samansuuruiset. Vuositulot oli karkeistettu jo ennen aineiston luovutusta niin, että ne, jotka ansaitsevat vuodessa 200000 euroa tai enemmän, oli niputettu yhteen. Aiempien tutkimusten perusteella voimme päätellä, että analyysiin valitut muuttujat ovat opiskelijoita selvästi erottavia tekijöitä (ks. esim. Huberty, Jordan \& Brandt 2005; Bahr 2010).

Ennen analyysiä muuttujat standardoitiin. K-keskiarvoklusterianalyysissä ryhmien määrä on kiinnitettävä etukäteen. Useiden kokeilujen jälkeen parhaimmaksi osoittautui neljän ryhmän malli: ryhmät olivat sisäisesti homogeenisiä, poikkesivat toisistaan selvästi, ja kuhunkin ryhmään lukeutui "riittävä" määrä havaintoja. Koska aineistossa oli puuttuvia tietoja, läheskään kaikki havainnot eivät tulleet lopulliseen malliin mukaan. Lopullisessa mallissa oli kaikkiaan 13723 tapausta, mikä on 58 prosenttia koko aineistosta. Nimesimme ryhmät seuraavaan tapaan: 1) 'koulutustikkailla kohonneet', 2) 'koulutuspääoman uusintajat', 3) 'ikuiset opiskelijat' ja 4) 'toisen mahdollisuuden käyttäjät' (taulukko 1). Koulutuselämäkertakirjoitelmia hyödynsimme tulkinnan apuvälineinä, eli tarkastelimme erityisesti sitä, miten kirjoittajat kuvasivat koulutuspolkuaan ja selittivät valintojaan. Yleisen tason tarkastelussa ovat aluksi mukana kaikki 42 koulutuselämäkertaa. Lähempään tarkasteluun valitsimme neljä edustavaa koulutuselämäkertaa, joiden kirjoittajat sopivat taustoiltaan tilastollisen aineiston perusteella syntyneeseen kuvaan toisen mahdollisuuden käyttäjistä.

Kirjoitelmia analysoitaessa kiinnitimme huomiota erityisesti kolmeen keskeiseen teemaan, joita olivat 1) suhde koulunkäyntiin, 2) uravalintatilanne lukion jälkeen ja 3) yliopistoon hakeutumisen vaihe. Teemojen kautta pyrimme löytämään vastauksen toiseen tutkimuskysymykseemme: miksi yliopistoon oli hakeuduttu vasta aikuisiällä? 


\begin{tabular}{|l|r|r|r|r|}
\hline & $\begin{array}{l}\text { (1) Koulutus- } \\
\text { tikkailla } \\
\text { kohonneet }\end{array}$ & $\begin{array}{l}\text { (2) Koulutus- } \\
\text { pääoman } \\
\text { uusintajat }\end{array}$ & $\begin{array}{l}\text { (3) lkuiset } \\
\text { opiskelijat }\end{array}$ & $\begin{array}{l}\text { (4) Toisen } \\
\text { mahdollisuuden } \\
\text { käyttäjät }\end{array}$ \\
\hline Keski-ikä & 27 & 26 & 34 & 37 \\
\hline Lasten lukumäärä & 0 & 0 & $0-1$ & $2-3$ \\
\hline $\begin{array}{l}\text { Opintojen aloituksesta } \\
\text { kulunut aika }\end{array}$ & 4 & 4 & 9 & 5 \\
\hline $\begin{array}{l}\text { Korkeimman tutkinnon } \\
\text { suoritt. kulunut aika }\end{array}$ & 2 & 2 & 6 & 7 \\
\hline Vuositulot & 15832 & 15531 & 48578 & 31114 \\
\hline Äidin koulutustaso & keskiaste & ylempi kk-aste & alin kk-aste & keskiaste \\
\hline Isän koulutustaso & keskiaste & ylempi kk-aste & ylempi kk-aste & keskiaste \\
\hline Äidin vuositulot & 32205 & 61144 & 33120 & 29193 \\
\hline Isän vuositulot & 40942 & 88012 & 49850 & 41961 \\
\hline N (\%) & $6197(45 \%)$ & $4721(34 \%)$ & $1478(11 \%)$ & $1327(10 \%)$ \\
\hline
\end{tabular}

Taulukko 1. Yliopisto-opiskelijoiden neljä pääryhmää

\section{TILASTOAINEISTOSTA PIIRTYVÄ KUVA} TOISEN MAHDOLLISUUDEN KAYTTAJISTA

Klusterianalyysin avulla muodostetut ryhmät nimesimme siten, että nimessä korostuu erityisesti se tekijä, jonka suhteen kyseinen ryhmä eroaa muista. Aineistosta erottui kaksi nuorempien ja kaksi vanhempien opiskelijoiden ryhmää. Kaksi nuorempaa ryhmää nimesimme 'koulutustikkailla kohonneiksi' ja 'koulutuspääoman uusintajiksi'. Kohonneiden vanhemmilla oli selvästi muita matalampi koulutus, uusintajien vanhemmilla oli puolestaan korkein koulutus (taulukko 1)

Kaksi vanhempaa ryhmää nimesimme 'ikuisiksi opiskelijoiksi' ja 'toisen mahdollisuuden käyttäjiksi'. Ikuiset opiskelijat olivat opiskelleet pisimpään. Vaikka heidätkin voidaan määritellä aikuisiksi opiskelijoiksi, he olivat aloittaneet opintonsa yleensä nuoruusiässä. Toisen mahdollisuuden käyttäjät taas olivat jo aiemmin tutkinnon suorittaneita ja työelämässä olleita, jotka olivat aloittaneet yliopisto-opintonsa selvästi aikuisiällä.

Toisen mahdollisuuden käyttäjät olivat kaikkein vanhimpia, keski-iältään 37-vuotiaita. Naisten osuus ryhmäläisistä oli suurempi kuin muissa ryhmissä:
66 prosenttia oli naisia, kun kaikista yliopisto-opiskelijoista naisten osuus oli 57 prosenttia. Suurin osa 77 prosenttia, ryhmään kuuluvista oli naimisissa, ja lapsia oli yleisimmin kaksi tai kolme. Muista ryhmistä toisen mahdollisuuden käyttäjät erosivat siinä että kaupunkien ulkopuolella asuvien osuus oli selvästi suurempi: miltei 18 prosenttia asui maaseudulla tai taajamassa, kun koko aineistossa ei-kaupunkilaisten osuus oli vajaat yhdeksän prosenttia. Ei-ylioppilaiden osuus oli niin ikään ryhmässä hieman keskimääräistä suurempi , kahdeksan prosenttia.

Toisen mahdollisuuden käyttäjät olivat aloittaneet yliopisto-opintonsa keskimäärin viisi vuotta aiemmin, eli useimmat olivat aloittaneet opintons vasta yli 30-vuotiaina. Ennen maisteriopintoja suoritetut tutkinnot olivat tyypillisimmin (60\%) alemmalta korkeakouluasteelta, ja aloina olivat erityisest kaupallinen ja yhteiskuntatieteellinen, tekniikka humanistinen ja taideala sekä terveys- ja sosiaalial Koska kyseessä ovat maisteriopiskelijat, alemmat korkeakoulututkinnot ovat usein nimenomaan kanditutkintoja, joiden jälkeen useimmat jatkavat saman alan maisteriopintoihin.

Yksittäisistä ammateista yleisimpiä olivat opettaja, mukaan lukien lastentarhanopettaja, eri alojen
TOISEN MAHDOLLISUUDEN

K ̈̈YTT ̈̈J̈̈T OLIVAT

KAIKKEIN VANHIMPIA.

erityisasiantuntijat, sairaanhoitaja, kirjanpitäjä ja sihteeri. Yliopistoon toisen mahdollisuuden käyttäjät olivat tulleet opiskelemaan eritoten yhteiskuntatieteitä, kasvatustieteitä, terveys- ja hoitotieteitä, taidealaa, sotatieteitä ja liikuntatieteitä eli aloja, joita tutkimuksissa pidetään aikuisille suhteellisen helppopääsyisinä aloina (Nori 2011; Rinne ym. 2008) Terveystieteiden ja sotatieteiden maisteriopintoihin päästäkseen hakijalla tulee olla saman alan ammatillinen tutkinto, minkä vuoksi näillä aloilla opiskelevat ovat käytännössä lähes aina aikuisia.

Toisen mahdollisuuden käyttäjissä oli muiltakin kuin alemmalta korkeakouluasteelta valmistuneita. Ylemmän korkeakoulututkinnon oli suorittanut peräti 33 prosenttia ryhmään kuuluvista. Tutkijakoulutuksen saaneita oli noin kaksi prosenttia. Keskiasteen tutkinto oli vajaalla viidellä prosentilla alimman korkea-asteen tutkinto vajaalla prosentilla. Karkeasti ottaen toisen mahdollisuuden käyttäjät jakautuivat kahteen ryhmään: 1) ensimmäistä kertaa yliopistoon hakeviin ja 2) aiemmin yliopistotutkinnon suorittaneisiin alanvaihtajiin.

Vaikka tilastoaineisto antaa yleiskuvan toisen mahdollisuuden käyttäjistä, sen avulla ei pysty selvittämään, miksi yliopistoon on hakeuduttu vasta aikuisiällä. Sen vuoksi täydennämme toisen mahdollisuuden käyttäjien kuvausta analysoimalla heidän kirjoittamiaan koulutuselämäkertoja

AIKUISOPISKELIJOIDEN

\section{KOULUTUSELÄMÄKERRAT}

Lähes kaikki koulutuselämäkertansa kirjoittaneet aikuisopiskelijat olivat suorittaneet jonkin ammatillisen tutkinnon, ja heillä saattoi olla takanaan mittava työura. Tie yliopistoon oli ollut pitkä ja polveileva. Kuvailemme aluksi yleisellä tasolla kirjoittajien lähtökohtia, koulukokemuksia, suhdetta koulunkäyntiin ja koulutuksen siirtymävaiheita. Sen jälkeen tarkastelemme neljän naisen - Johannan, Merjan Liisan ja Sarin - koulutuselämäkertojen perusteella millaiset seikat olivat viivästyttäneet yliopisto-opintojen aloittamista ja missä vaiheessa päätös opiskelemaan lähtemisestä oli kypsynyt. Naisten nimet on muutettu. Kiinnitämme erityistä huomiota siihen, oliko opiskelijoiden elämänkulussa jokin käännekohta (ks. O'Shea 2014), joka oli muuttanut koulutuspolun suunnan ja saanut hakeutumaan yliopistoon keskimääräistä vanhempana.

Koulutuselämäkertansa kirjoittaneista suurin osa, 40, oli naisia. Joukossa oli vain kaksi miestä, joiden tarinat eivät kuitenkaan oleellisilta osin poikenneet naisten tarinoista. Runsas puolet vastaajista ol yli 30-vuotiaita ja lähtöisin työntekijä- tai maanviljelijäperheistä. Yhdeksännen luokan jälkeen useimmat $(85 \%)$ jatkoivat opintojaan lukiossa, mutt jotkut olivat lähteneet ammattikouluun, päättäneet pitää välivuoden tai jääneet kymppiluokalle korottamaan numeroitaan ja miettimään tulevaisuuttaan (taulukko 2). Lukioon suuntautuneet perustelivat usein valintaansa sillä, etteivät he keksineet muutakaan vaihtoehtoa. Näin totesivat etenkin kouluss enintään keskitasoisesti menestyneet. Jos lisäks useimmat kaveritkin siirtyivät lukioon, valinta o ollut helpompi, vaikka koulunkäynti ei olisi erityisemmin kiinnostanutkaan.

Noin puolet aikuisopiskelijoista kertoi koulutuselämäkerrassaan olleensa peruskoulussa ja toisell asteella keskitason oppilaita. Tarinoiden perusteell suurimmalla osalla keskitasoisesti menestyneistäkin olisi ollut edellytyksiä saada parempia arvosanoja mutta eri syiden vuoksi koulumenestys jäi keskinkertaiseksi.

Joillakin alisuoriutuminen koulussa johtui siitä, että kaverit ja harrastukset olivat teinivuosina menneet koulunkäynnin edelle. Toisilla taas esimerkiks koulukiusatuksi joutuminen, teiniraskaus tai sairaudet olivat vaikeuttaneet keskittymistä koulunkäyntiin. Monissa tarinoissa muisteltiin myös, kuink lapsuudenperheen ongelmat, kuten vanhempien köyhyys, päihdeongelmat tai avioero, olivat heijastuneet eri tavoin koulumaailmaan. 


\begin{tabular}{|l|r|r|}
\hline Tarinan kirjoittaneiden ikäjakauma & $\%$ & $\mathbf{N}$ \\
\hline 26-30-vuotiaat & 45 & 19 \\
\hline $31-40$-vuotiaat & 40 & 17 \\
\hline 41-50-vuotiaat & 15 & 6 \\
\hline Lapsuuden perhe & 59 & 25 \\
\hline Työntekijä-/maanviljelijäperhe & 41 & 17 \\
\hline Toimihenkilöperhe & & \\
\hline Koulumenestys (peruskoulussa ja toisella asteella) & 48 & 20 \\
\hline Hyvä & 45 & 19 \\
\hline Keskitasoinen & 5 & 2 \\
\hline Heikko & 2 & 1 \\
\hline Ei tietoa & & \\
\hline Koulutusvalinta peruskoulun jälkeen & 85 & 36 \\
\hline Lukio & 10 & 4 \\
\hline Ammattikoulu & 5 & 2 \\
\hline Muu (välivuosi tai kymppiluokka) & & \\
\hline Nykyinen tieteenala yliopistossa & 55 & 23 \\
\hline Hoitotiede & 21 & 9 \\
\hline Kasvatustieteet (kasvatustiede/aikuiskasvatustiede/erityispedagogiikka) & 12 & 5 \\
\hline Yhteiskuntatieteet (sosiologia, sosiaalipolitiikka, sosiaalityö) & 12 & 5 \\
\hline Muut tieteenalat &
\end{tabular}

Taulukko 2. Koulutuselämäkerran kirjoittaneiden aikuisopiskelijoiden taustatiedot.

Lähes kaikilla koulutuselämäkertansa kirjoittaneilla oli ammattikoulu- tai ammattikorkeakoulututkinto. Noin puolet kirjoittajista oli suorittanut tutkintonsa terveydenhoitoalan oppilaitoksessa; tutkintonimikkeinä oli sairaanhoitaja, lähihoitaja, ensihoitaja tai suuhygienisti. Vain kaksi oli hakeutunut muutamien työssäolovuosien jälkeen yliopisto-opintoihin pelkästään lukion käyneenä. Joukossa oli lisäksi viisi henkilöä, jotka olivat suorittaneet jo aiemmin yliopistotasoisia opintoja: kahdella oli ylempi korkeakoulututkinto, kahdella alempi korkeakoulututkinto, ja yksi oli keskeyttänyt korkeakouluopintonsa.

Koulutuselämäkerran kirjoittaneista valtaosa opiskeli pääaineenaan hoitotiedettä, kasvatustieteitä tai yhteiskuntatieteitä, eli aikuisopiskelijoille tyypillisimpiä aloja.

Aikuisopiskelijoiden tarinoista selviää, miksi yliopistoon lähtö oli heillä viivästynyt. Kaksi opiskeli pääaineenaan hoitotiedettä, toiset kaksi kasvatustieteitä tai humanistista alaa.

\section{Opiskelumotivaation ja oman alan löytyminen}

Koulutuselämäkertansa kirjoittaneet toisen mah dollisuuden käyttääät voidaan jakaa kahteen eri tavoin ammatillisesti suuntautuneeseen ryhmään. Ensimmäiseen ryhmään kuuluvat hoitotieteilijät, joita oli noin puolet koulutuselämäkerran kirjoittaneista. Heillä opintojen aloittaminen aikuisena on ymmärrettävää, koska koulutukseen pääsy edellyttää

\section{MYÖNTEISET}

OPPIMISKOKEMUKSET

JA OPINTOMENESTYS

ROHKAISIVAT HANKKIMAAN

LIS $\dddot{A}$ KOULUTUSTA.

aiempaa terveydenhoitoalan ammattitutkintoa. Hoitotieteen opiskelijoista moni oli aiemmin kohdannut vaikeuksia koulutuspolullaan, mutta lopulta löytänyt oman alansa ja oppimisen ilon. Opinnoissa menestyminen oli merkittävä käännekohta, joka muutti käsityksen itsestä oppijana.

Johannan tarina tuo esiin sen, kuinka myönteiset oppimiskokemukset ja hyvä opintomenestys olivat lisänneet uskoa omiin kykyihin ja samalla rohkaisseet asettamaan tavoitteet korkeammalle ja hankkimaan lisää koulutusta.

"Löysin opiskelun ilon ja kunnianhimon itsestäni! Minusta tuli 'hikari'. Opiskelu oli helppoa ja olin oikeasti kiinnostunut opetettavista asioista. Sain kiitettäviä arvosanoja ja panostin opiskeluun täysin uudenlaisella innolla. Valmistuin vuosikurssin parhailla arvosanoilla ja sain elämäni ensimmäisen stipendin. Itsetuntoni alko nousta. Samoin opiskelunnälkäni kasvoi”

Hoitotieteilijöille tyypillistä oli työn ohella kouluttautuminen ja pyrkimys ammatillisen osaamisen atkuvaan kehittämiseen sekä uusien haasteiden kaipuu ja halu edetä uralla. Toisaalta he olivat usein kyllästyneitä työtehtäviin tai työyhteisössä vallitseviin käytäntöihin ja sairaalamaailman hierarkkisuuteen. Lisäksi perhe- ja työelämän yhdistämisen vaikeus saattoi olla yksi motiivi hakeutua aikuiskoulutukseen. Monien erilaisten tekijöiden summana oli voinut lopulta kypsyä päätös lähteä jatkamaan opintoja yliopistoon. Johannalle opiskeleminen merkitsi ennen kaikkea väylää, jonka kautta edetä uralla ja päästä yhä mielenkiintoisempiin työtehtäviin.
"Pidin työstäni ja koin tekeväni vastuullista ja haastavaa työtä. Olin siitä ylpeä. Vuosien kuluessa kuitenkin työn haasteellisuus ei enää tuntunut riittävältä ja ajatus opiskelusta alkoi taas vilahdella mielessä [--] Nyt alkaa olla vuosi opintoja takana ja alan oikeasti uskoa siihen, että parin vuoden päästä valmistun maisteriksi. Olen valtavan onnellinen, että löysin itsestäni sen kunnianhimon ja ilon opiskeluun. Nyt haaveetkin ovat kasvaneet, enkä pidä ollenkaan mahdottomana jatko-opintojakaan."

Hoitotieteilijöillä yliopisto-opinnot olivat osa samaa ammatillista jatkumoa, joka oli saanut alkunsa jo nuorella iällä. Toisen mahdollisuuden käyttäjien toinen pääjoukko koostuu sen sijaan aikuisopiskelijoista, joilla oli usein takanaan monialainen koulutus- ja työhistoria. Koulutuselämäkertojen perusteella omaa paikkaa oli etsitty kauan, eivätkä kaikki olleet vielä tarinaa kirjoittaessaankaan varmoja, oliko tie oikea. Jotkut tuntuivat kuitenkin löytäneen paikkansa ja olivat tyytyväisiä nykyiseen elämäntilanteeseensa.

Tarinat muistuttavat monin tavoin kuuden laudaturin ylioppilaiden elämänkulkua kuvaavassa tutkimuksessa mukana olleiden 'etsijöiden' kertomuksia, joissa he kuvailivat mutkikasta koulutus- ja työuraansa. Oman paikan löytämisen vaikeus näytti koulumenestyjillä usein olevan yhteydessä siihen, ettei heillä ollut lähipiirissä uravalinnan suunnannäyttäjiä tai läheisten vahvaa tukea koulutusvalintojen teossa. (Vanttaja 2002.) Vastaavanlaisessa tilanteessa olivat olleet myös monet tähän tutkimukseen osallistuneet aikuisopiskelijat.

\section{Työläisperheestä yliopistoon}

Etenkin työläisperheessä varttuneiden kirjoittajien tarinoissa koulutusvalintojen vaikeudet olivat usein sidoksissa vanhempien koulutuspääoman niukkuuteen. Hyväkään koulumenestys ei välttämättä kompensoinut koulutusvalinnoissa tarvittavan tuen ja kulttuuristen resurssien puutetta.

Laudaturpaperein ylioppilastutkinnosta suoriutunut työläistaustainen Merja oli harkinnut lukion jälkeen Taideteolliseen korkeakouluun pyrkimistä, mutta koska hän ei uskonut selviävänsä tiukoista pääsykokeista, hakeminen oli jo etukäteen tuntunut turhalta. 
KODIN TALOUDELLISET,

KULTTUURISET JA

SOSIAALISET PÄAOOMAT

VAIKUTTAVAT

KOULUTUSVALINTOIHIN.

Toisena vaihtoehtona ollut yliopistollinen koulutusala jäi haaveeksi, koska se olisi vaatinut muuttamista yksin suureen kaupunkiin ja kauaksi kotoa.

Yliopistokoulutuksen hylkääminen näytti liittyvän kodin taloudellisten, kulttuuristen ja sosiaalisten pääomien niukkuuteen (esim. Bourdieu 1986; Bourdieu \& Wacquant 1995). Merja oli omassa kasvuympäristössään oppinut asettamaan koulutustavoitteensa matalammalle tasolle kuin koulumenestys olisi mahdollistanut. Merjan omin sanoin ilmaistuna, yliopisto-opintojen hylkäämisen syynä oli "liian pitkä henkinen ja fyysinen välimatka":

"Helpointa oli hakea ammatillisiin oppilaitoksiin, joihin valittiin todistusten perusteella. [--] Järkeilin niin, että kannattaa ensin hankkia ammatillinen koulutus, ja jatkaa opintoja, vaikka sitten myöhemmin, ja vaikka vielä sellaisella alalla, joista olin tuolloin lievästi kiinnostunut. Kaupallisen koulutuksen ajattelin antavan aika laajat ja varmimmat valmiudet sijoittua erilaisiin työtehtäviin - vaikka kulttuurin tai taiteen alalla."

Yliopistokoulutukseen hakeutuminen edellytti monilla muillakin työläistaustaisilla kirjoittajilla jonkinlaista kypsymisvaihetta, jonka aikana he oppivat tuntemaan itseään sekä omia kiinnostuksen kohteita ja vahvuusalueita. Lukion jälkeen monet olivat pitäneet ensin välivuoden tai useita ja menneet töihin, koska epävarmuus itselle sopivasta alasta vaikeutti valintojen tekemistä.

Jotkut löysivätkin oman kiinnostuksen kohteen juuri välivuosien aikana töissä ollessaan, jolloin he päättivät hakeutua opiskelemaan työtään vastaavalle koulutusalalle. Toiset taas esimerkiksi tutustuivat yliopistomaailmaan ensin työn kautta, kuten Merja, joka päätyi yliopistoon toimistotöihin. Akateeminen maailma oli hänelle vielä työuran alkuvaiheessa täysin vieras.

"Tuttaviini ei ollut kuulunut ketään, joka olis opiskellut tai työskennellyt korkeakoulussa. Alussa oli monia uusia asioita, termejä, sääntöjä ja tapoja, joihin piti perehtyä, ja opetella puhumaan samaa kieltä yliopistolaisten kanssa. Onneksi henkilökunta oli ymmärtäväistä, ja kaikki kohtelivat työyhteisön tulokasta tasa-arvoisesti. [-Ja ehkä tuo kokemus ja filosofisten keskustelujen seassa työskenteleminen loivat ja voimistivat käsitystä siitä, että kysyminen, erilaiset näkökulmat, pohdinta ja keskustelu sekä tiedon muodostaminen on sinänsä merkittävää ja kiinnostava ja kaikkien ulottuvilla, koska siihen tarvittavat resurssit ja työkalut ovat itse kullakin korvien välissä, kirjojen lisäksi tietenkin.”

Merja ryhtyi suorittamaan työn ohessa ensin avoimen yliopiston kursseja ja hakeutui yliopisto-opiskelijaksi vasta oltuaan neljä vuotta työssä. Selviä urasuunnitelmia tai toiveammattia hänellä ei ollut, mutta opinnot etenivät silti erinomaisin arvosanoin. Opiskelusta tuntui kuitenkin puuttuvan punainen anka. Tulevaisuuden epävarmuus ja toimeentuloongelmat varjostivat aikuisopiskelijan arkea.

Merja nosti ensimmäisinä opiskeluvuosina opintolainaa,"mutta sitten alkoi hirvittää, että millä sen ikinä maksan korkoineen pois, koska humanistien työllistyminen näytti epävarmalta. Sen jälkeen rahoitin opiskeluni ja elämiseni tekemällä töitä myös lukuvuoden aikana”. Vuosien mittaan työssäkäynti alkoi mennä yhä enemmän opintojen edelle, ja lopulta opinno keskeytyivät perheen perustamisen ja lasten syntymän jälkeen. Tämän jälkeen yliopisto-opintoihin tul lähes parin vuosikymmenen mittainen tauko, koska päätoiminen työ ja vanhemmuus täyttivät elämän.

Vaikka tutkintotavoitteinen opiskelu oli ollut pitkään jäissä, Merjan elämän varrelle mahtui runsaast työnantajan tarjoamaa koulutusta, työssä oppimista ja omaehtoista opiskelua. Hän hakeutui myöhemmin uudelleen yliopistoon, koska halusi täydentä tietojaan työhönsä liittyvistä asioista. Opintojen loppuunsaattamisen kannalta tulevaisuus näytti kuitenkin hankalalta, koska päätoimisen työn ohella opis- kelu tuntui mahdottomalta. Aikuisopintotukeen tehdyt heikennykset vaikeuttivat tilannetta vielä entisestään, sillä " aikuisopiskelu- ja vuorotteluvapaatuet eivät pienituloista yksinhuoltajaa elätä. Sinnittelen, ja odottelen sopivaa tilaisuutta".

Merjan tarina on kuvaus työläistaustaisesta opiskelijasta, joka on aina joutunut huolehtimaan itse toimeentulostaan, ilman, että taustalla olisi tukijoukkoja, jotka voisivat tiukan paikan tullen auttaa taloudellisesti. (Ks Reay 2003; Archer \& Hutchings 2000.) Varakkaammista perheistä tulleet opiskelijatkaan eivät välttämättä joudu koskaan tukeutumaan vanhempiensa taloudelliseen apuun, mutta pelkkä tietoisuus avun mahdollisuudesta luo henkistä varmuutta ja tulevaisuudenuskoa. Hyvätuloisista perheistä tulleille opiskelijoille saattaa esimerkiksi olla muita helpompaa tehdä erilaisia koulutuksellisia kokeiluja ja ottaa riskejä, koska niiden seuraukset eivät ole taloudellisesti yhtä kohtalokkaita kuin vähävaraisen perheen jälkikasvulle.

\section{Yliopisto yksinhuoltajan pakoreittin}

Merjan kertomuksen tapaan usean tarinan yksi keskeinen juonenkäänne oli yksinhuoltajaksi jääminen ja siitä aiheutuneet ongelmat. Lukion jälkeen ammatillisen tutkinnon suorittanut Liisa oli heti valmistuttuaan onnistunut saamaan hyvän työpaikan suuren yrityksen palveluksesta, perustanut perheen ja hankkinut asuntolainan. Elämä tuntui sujuvan mallikkaasti, kunnes avioero muutti tilanteen.

Pienten lasten yksinhuoltajana Liisa ei voinut jatkaa vuorotöissä vaan joutui hakeutumaan päivätöihin, joita omalla alalla oli niukasti tarjolla. Muutamia vuosia märäaikaisissa työsuhteissa sinniteltyään Liisa kyllästyi, ja kouluttautui uuteen ammattiin, mutta huomasi pian tulleensa siinä samanlaiseen umpikujaan kuin edellisessäkin. ”En kelvannut töihin edes perunoita pakkaamaan tai sikalaan. Perhe piti kuitenkin elättää ja päätin hankkia ammatin, jossa varmasti olisi töitä." Niinpä Liisa hakeutui työvoimapoliittiseen koulutukseen hoitoalalle, vaikka varsinaista kutsumusta alalle ei ollutkaan. Opinnot sujuivat silti hyvin ja tutkinnon suorittamisen jälkeen töitä löytyi heti.

Yksinhuoltajan oli kuitenkin vaikea sovittaa lastenhoitoa vuorotyön rytmiin. Kun sosiaalinen verkosto oli olematon, eikä lasten isä kantanut vastuutaan, hoitopaikkojen järjestäminen lapsille oli vaikeaa. Kaiken lisäksi lastenhoito-ongelmien vuoksi työpaikalla saatu erityiskohtelu ja työaikajoustot herättivät kollegoissa närkästystä ja kateutta.

Liisa kertoo lopulta väsyneensä hankalaan työtilanteeseen sekä jatkuvaan stressiin ja päättäneensä sen vuoksi hakeutua opiskelijaksi yliopistoon. Pääsykoekirjat hän totesi lukeneensa todella huolellisesti, koska heikon ylioppilastutkintotodistuksen kompensoimiseksi pääsykokeesta oli pakko saada huippupisteet. Onnistuneen pääsykokeen jälkeen yliopiston ovet avautuivat. Opintojen alussa koetun tentissä epäonnistumisen jälkeen mieltä kuitenkin kalvoi epävarmuus omista kyvyistä ja voimavaroista.

"Jouduin kohtaamaan pelkoni siitä, että olen liian tyhmä yliopisto-opiskelijaksi, enkä pääse mistään kursseista läpi. Lisäksi ajattelin, että olin haukannut liian suuren palan yksinhuoltajaksi, jolla on jo muutenkin elämässä paljon vastoinkäymisiä. Nämä ajatukset ja tunteet tulvahtivat hyökyaallon lailla pintaan ja näin monta yötä painajaisia.”

Liisan tarinan keskiössä on vaikeus löytää työpaikkaa, joka turvaisi riittävän toimeentulon ja jossa huomioitaisiin yksinhuoltajan hankala elämäntilanne. Yliopistoopinnot tarjosivat pakoreitin pois tilanteesta, jossa työn ja lastenhoidon yhdistäminen näytti mahdottomalta.

Liisan tarina osoittaa, että opiskelu voi synnyttää hyvin ristiriitaisia tunteita, koska sitä ei välttämättä pidetä "oikeana työnä" vaan eräänlaisena välivaiheena matkalla kohti täysivaltaista kansalaisuutta.

"Haluaisin jo takaisin työelämään, olen opiskellut niin suuren osan elämästäni. Olen myös kohdannut sellaisia asenteita ympärilläni olevilta ihmisiltä, että opiskelen vain sen vuoksi, että en halua tehdä työtä. Se satuttaa, koska olen mielestäni tehnyt parhaani täyttäessäni yhteiskunnallisia velvollisuuksiani ja koen olevani rakenteellisten ongelmien vuoksi tilanteessa, jossa en ole pystynyt yhdistämään työtä ja perhettä. Välillä koen pettäneeni lapset, koska heillä on ollut nuoruus melkoista köyhäilyä yliopisto-opintojeni vuoksi. Toisaalta olen ylpeä itsestäni, koska uskalsin lähteä toteuttamaan unelmiani." 
HUIPPUOPPILAaLTA

ODOTETTIIN ERINOMAISIA

TULOKSIA.

Tarinassa tulee esille se, että aikuisten yliopistoopiskelijoiden koulutuselämäkerrat eivät aina ole vain myönteisiä kertomuksia "sosiaalisesta noususta", oppimisen ilosta tai toisen mahdollisuuden saamisesta ja uuden uran luomisesta. Usein kertomuksiin sisältyy myös kuvauksia opiskelun mukanaan tuomasta köyhyydestä, monenlaisista epävarmuuden tunteista, stressistä, uupumuksesta sekä perheen laiminlyömisen aiheuttamasta syyllisyydentunnosta.

\section{Suorituspaineet huippuoppilaan}

koulutusvalintojen taustalla

Peruskoulussa keskitasoisesti tai sitä heikommin menestyneille oppilaille oli ollut tyypillistä huoleton suhtautuminen koulunkäyntiin. Alisuoriutumisestaan huolimatta monet olivat jatkaneet peruskoulun jälkeen lukiossa, koska eivät omien sanojensa mukaan keksineet muutakaan vaihtoehtoa.

Keskitason oppilaiden lisäksi joukossa oli kuitenkin monia hyvin tai jopa huippuarvosanoin suoriutuneita oppilaita, joille lukioon siirtyminen peruskoulun jälkeen oli ollut itsestään selvä vaihtoehto. Heille ongelmia saattoivat aiheuttaa juuri koulumenestyksen mukanaan tuomat suorituspaineet ja täydellisyyden tavoittelu. Huippuoppilaan ei sopinut epäonnistua, sillä kaikki odottivat erinomaisia tuloksia.

Sarin tarinasta käy hyvin ilmi, miten identiteetti voi alkaa pikkuhiljaa rakentua pelkästään koulumenestyksen varaan ja johtaa lopulta uupumukseen.

Kokeesta oli saatava kymppi, mielellään täysin pistein [--] Mutta koulumenestys luo myös valtavat paineet. Ja noiden paineiden alle lukioaikanani muserruin. [--] Minulla oli itse rakentamani ja ympäröivän yhteisön varmasti tietämättäänkin ruokkima paine suoriutua kaikesta täydellisesti. [--] Kun itsetunto oli vasta kehittymässä ja perustui liiaksi koulumenestykseen, ei ylisuorittamisesta pitäytyminenkään onnistunut. Niin minä jatkoin tutulla tiellä muuttuen samalla innokkaasta koululaisesta väsyneeksi ja ahdistuneeksi opiskelijaksi, joka ei halunnut elää niin, muttei muutakaan osannut"

Väsymyksestä huolimatta Sari sai ylioppilaskirjoituksista huipputodistuksen, jonka turvin hän olisi voinut heti lukion jälkeen hakeutua yliopisto-opintoihin mutta koulussa koetut liialliset suorituspaineet viitoittivat tien alemmalle koulutustasolle. Kympin oppilaalta tällaista koulutusvalintaa saatetaan usein pitää lahjakkuuden haaskauksena (ks. Vanttaja 2002). Sari olikin saanut kuulla opinto-ohjaajaltaan moitteita päätöksestään hakeutua lukion jälkeen sairaanhoito-oppilaitokseen. Sarin kotona ratkaisuun oltiin kuitenkin tyytyväisiä. Vanhemmat olivat ähneet, miten voimakkaasti suorituspaineet olivat heidän tytärtään rasittaneet ja ymmärsivät hyvin koulutusvalinnan syyt.

"Kaikki sukulaiseni eivät olleet yhtä ymmärtäväisiä, vaikka vanhempani heille vuolaasti kertoiva nopeaa päätöksentekoa vaativan, vastuullisen ammatin sopivan minulle hienosti ja tukivat päätöstäni ehdottomasti. Jälkikäteen olen miettinyt että kunpa he olisivat ohjanneet minua pitämään välivuoden. Itse en sellaista uskaltanut ehdottaa, koska jotenkin se olisi tuntunut luovuttamiselta, kyllähän minun nyt piti opiskelemaan hakea. Olin haaveillut myös journalismin opiskelusta. Varmasti juuri lama-ajan kokemukset kuitenkin olivat iskostaneet päähäni, etten voisi hakeutua ammattiin, jossa työn saaminen ei olisi varmaa. Riskien ottaminen ei sopinut ajatusmaailmaani”.

Huippuoppilaalle erilaisia koulutusvaihtoehtoja on periaatteessa tarjolla runsaasti. Laajasta valikoimast huolimatta kukaan ei tosiasiassa pidä kaikkia tarjoll olevia koulutuksellisia ja ammatillisia vaihtoehtoja itselle sopivina. Yksilön käsitys itsestään, mahdollisuuksistaan ja sopivista uravaihtoehdoista muotoutuu vuorovaikutuksessa ympärillä olevien ihmisten kanssa ja siinä kulttuurissa, jossa hän elää. Uravalinnassa voi näkyä muun muassa se, millaisia asioita yksilö on oman elämänhistoriansa kuluessa oppinut arvostamaan ja pitämään tavoiteltavana. Arvostukset ja tavoitteet puolestaan ovat yhteydessä esimerkiksi sukupuoleen, sukupolveen, kotitaustaan ja kulloiseenkin historialliseen aikakauteen. (Vanttaja 2002, 251.)

Sarin koulutuselämäkerta tekee ymmärrettäväksi miksi hän päätti erinomaisesta koulumenestyksestä huolimatta hylätä teoreettiset yliopisto-opinnot ja valita käytännöllisemmän vaihtoehdon hakeutumalla hoitoalalle. Koulutusvalintaan vaikuttivat niin yksilölliset kuin yhteiskunnan rakenteelliset tekijät. Kuten Sari toteaa, läksyjen parissa puurtamiseen kyllästyminen ja lama-ajan luoma epävarmuus vaikuttivat omalta osaltaan uravalintaan. Ratkaisua vo pitää luontevana myös sen vuoksi, että hänen äitins di hoitoalalla ja tuki tyttärensä valintaa. Omassa kotiympäristössään Sari oli lisäksi oppinut arvostamaan käytännön taitoja, koska "äiti hallitsi myös kaikki kädentaidot." Sarin hakeutuminen hoitoalalle oli siten kontekstissaan ymmärrettävä ja rationaalinen valint (ks. Järvinen 1999, 193).

Sairaanhoito-oppilaitoksessa opintomenestys jatkui entiseen tapaan, mutta eniten tyydytystä Sari koki saaneensa työharjoittelujaksoista, jotka olivat hänell "todiste siitä, että en ollut vain 'kirjaviisas'." Sarille ol tärkeää osoittaa itselle ja muille, että hän kykeni äitinsä tapaan suoriutumaan kaikenlaisista työtehtävistä. Hän totesi kuitenkin päättäneensä jo lukion jälkeen, että hakeutuisi myöhemmin yliopistoon, hankittuaan ensin ammatin ja työkokemusta.

Sarin tarinassakin tuli esiin muille hoitotieteilijöill tyypillinen voimakas halu kehittyä omassa ammatissa ja etsiä uusia haasteita, mikä puolestaan sai heidät hakeutumaan yliopisto-opintoihin. Muista hoitotieteilijöistä poiketen Sarin tarinassa yliopisto-opintojen myöhäinen aloittamisikä liittyi kuitenkin pääasiass koulussa koettuihin suorituspaineisiin, joiden vuoks yliopistoon hakeutuminen heti lukion jälkeen oli tuntunut vastenmieliseltä vaihtoehdolta.

Sarin tarinassa esitetty ylisuorittamisen vaar saattaa vaania etenkin korkeasti koulutettujen vanhempien jälkikasvua. Vanhempien ja opettajien kunnianhimoisin vaatimuksiin vastaaminen vol helposti johtaa välineelliseen suorittamiseen ja oppimisen ilon hiipumiseen (Vanttaja 2002). Koulussa keskitasoisesti tai heikosti pärjänneiden tarinoissa usein toistuva teema oli sen sijaan opiskelumotivaation löytyminen ja koulumenestyksen saavuttaminen myöhemmällä iällä. Monet olivat huomanneet vasta lukion jälkeisissä opinnoissaan, että opiskelu voi olla kiinnostavaa, hauskaa ja palkitsevaa. Oppimisen ilon löytämisen lisäksi tärkeinä elämän käännekohtina mainittiin myös itsenäisen elämän aloittaminen ja perheen perustaminen

Perheelliset opiskelijat pitivät tärkeänä puolison antamaa tukea ja opiskeluun kannustamista. Opiskelemaan lähteminen olisi monessa tapauksessa ollut mahdotonta, ellei puoliso olisi ottanut päävastuuta lastenhoidosta. Lisäksi puolison tuella oli päästy irti esimerkiksi lapsena koulussa koetuista epäonnistumisen kokemuksista. Toisinaan puolison ja poikaystävän merkitys tuli kuitenkin tarinoissa esiin negatiivisella tavalla. Jotkut olivat hakeutuneet yliopistoon sen vuoksi, että parisuhteen solmittuaan he olivat päätyneet korkeasti koulutettuun sukuun ja alkaneet kokea alemmuudentunnetta omasta koulutuksestaan. Myöhemmin he olivat saattaneet katua yliopisto-opintoihin lähtemistä, koska valinta ei ollut perustunut aitoon kiinnostukseen vaan enemmänkin statushakuisuuteen ja pyrkimykseen täyttää muiden odotuksia.

\section{YLIOPISTOON HAKEUTUMISEN MONET SYYT}

Tarkastelimme 'toisen mahdollisuuden' käyttäjien profilia ja koulutuspolkuja. Tilastoaineiston perusteella keskimääräinen toisen mahdollisuuden käyttäjä on 37-vuotias perheellinen nainen, jolla on kahdesta kolmeen lasta. Hän on yleensä suorittanut aiemmin jonkin alemman korkea-asteen tutkinnon ja ollut sen jälkeen työelämässä. Muihin yliopisto-opiskelijoihin verrattuna toisen mahdollisuuden käyttäjissä on suhteellisesti enemmän ei-ylioppilaita ja kaupunkien ulkopuolella asuvia. Heidän vanhempansa ovat lisäksi pienituloisempia ja vähemmän koulutettuja kuin muilla yliopisto-opiskelijoilla keskimäärin.

Toisen mahdollisuuden käyttäjät ovat monin tavoin koulussa hyvin päriänneiden 'koulutuspääoman 
TOISEN MAHDOLLISUUDEN

KÄYTT ̈̈JISSÄ ON

SUHTEELLISESTI ENEMMÄN

EI-YLIOPPILAITA.

uusintajien' vastakohta (ks. taulukko 1). Uusintajille yliopistoon hakeutuminen heti ylioppilaskirjoitusten jälkeen on miltei itsestäänselvyys. He tulevat akateemisesti koulutetuista perheistä, joiden kulttuurisesta, sosiaalisesta ja taloudellisesta pääomasta on etua erityisesti koulutusvalintojen nivelvaiheissa.

Uusintajat näyttäisivät lisäksi olevan sitä joukkoa, joka eniten hyötyy esimerkiksi korkeakoulujen opiskelijavalintaa koskevista uudistuksista. Vuonna 2016 opiskelijavalinnoissa otettiin käyttöön ensikertalaiskiintiöt, joilla haluttiin parantaa niiden asemaa, jotka eivät vielä olleet ottaneet vastaan opiskelupaikkaa korkeakoulusta. Opiskelijavalintoihin tehtävien uudistusten yksi tavoite on ollut myös lisätä ylioppilastutkinnon painoarvoa valinnoissa. Uudistusten myö-

tä koulutuspääoman uusintajien osuus opiskelijoista mitä ilmeisimmin kasvaa.

Sen sijaan toisen mahdollisuuden käyttäjien osuus todennäköisesti vähenee uudistusten myötä. Toisen mahdollisuuden käyttäjät löytävät usein opiskelumotivaation ja oppimisen ilon vasta aikuisiällä. Heidän aiempi koulumenestyksensä on voinut olla vaatimatonta, mutta yliopistojen pääsykokeet ovat olleet hyvä paikka osoittaa motivoituneisuutta ja kyvykkyyttä. Yliopistoon hakeminen voi siis monille olla todellisuudessa aito "toinen mahdollisuus", johon ei ennen ole ehkä rohjennut tarttua. Näin opiskelijavalintauudistus toimii elinikäisen oppimisen periaatteen vastaisesti, koska se heikentää erityisesti aikuisopiskelijoiden yliopisto-opiskelumahdollisuuksia.

Tutkimistamme koulutuselämäkerroista käy ilmi, että aikuisena yliopisto-opiskelijaksi hakeutumiseen saattoi samallakin henkilöllä olla useita syitä. Yleisin syy oli halu kehittyä ammatissa ja edetä uralla kouluttautumisen avulla.
Useissa tapauksissa itseä kiinnostava koulutusala oli löytynyt vasta useiden työvuosien jälkeen ja elämänkokemuksen kartuttua. Monet kertoivat löytäneensä opiskeluinnon vasta lukion jälkeen ammatillisissa opinnoissa. Tyypillinen syy oli sekin että pitkään samassa työssä oltuaan ihmiset kokivat turhautuvansa ja haaskaavansa resurssejaan. Muutamissa tapauksissa kouluttautumispäätös oli syntyny äitiysloman loppuvaiheessa, kun olisi pitänyt siirtyä takaisin työelämään. Opiskelu oli siinä vaiheessa tuntunut mielekkäämmältä vaihtoehdolta kuin esimerkiksi siirtyminen lasten hoitamisen kannalt hankalaan epäsäännölliseen vuorotyöhön ja heikosti palkattuihin pätkätöihin.

Aikuisopiskelijoiden koulutuselämäkerrat tuovat esiin myös sen, että kaikille yhteisestä peruskoulusta ja koulutusmahdollisuuksien näennäisestä tasa-arvost huolimatta erilaiset yksilöstä riippumattomat tekijät ovat yhteydessä koulunkäynnin sujumiseen ja koulutuksen siirtymävaiheiden valintoihin. Vaikka ihmisten voi ajatella valitsevan vapaasti oman koulutus- ja ammattiuransa, he joutuvat kuitenkin tekemään valintansa kulttuurisessa kontekstissa, jota eivät ole itse valinneet. (Ks. Muhonen 2013; Vanttaja 2002.

Kukaan ei esimerkiksi voi valita vanhempiaan, geneettistä perimäänsä, kulttuuriaan tai kasvuympäristöään. Ne kuitenkin muokkaavat identiteettiämm ja vaikuttavat siihen, millaisia ihmisiä olemme ja millaisia meistä voi tulla. Elämänhistorian aikana kokemusten myötä muotoutunut käsitys itsestä ja omist mahdollisuuksista suuntaa valintoja ja rajaa vaihtoeh dot, joita ihmiset pitävät itselle sopivina (Hodkinson \& Sparkes 1997).

Aikuisopiskelijoiden tarinat osoittavat, että kouluttautumisen merkitykset eivät rajoitu pelkästään uusien tietojen ja taitojen hankkimiseen vaan $\mathrm{n}$ voivat olla moniulotteisia. Joillekin koulutus oli ollut keino irtautua lapsuudenkodin vaikeista olosuhteista ja lannistavasta ilmapiiristä. Kouluttautumista oli käytetty pakoreittinä pois hankalasta elämäntilanteesta Vastaavanlaisia kokemuksia koulutuksen merkityksestä on tullut jo aiemmin esille esimerkiksi koulumenestyjien elämäntarinoihin pohjautuvassa tutkimuksessa (Vanttaja 2002). Koulutus toimii tällöin uuden identiteetin ja paremman elämän rakennusmateria lina. Mercerin (2007) tapaan voidaan puhua minuuden uudelleenneuvottelusta tai rakentamisesta, joss elämän suuntaa ja omaa paikkaa on mahdollista tarkistaa vielä aikuisiässä.

Opiskelun avulla uutta uraa ja elämää luodessaan moni oli joutunut tinkimään paitsi elintasostaan myös läheisten kanssa viettämästään ajasta. Vaatimattomissa kotioloissa varttuneille työläistaustaisille opiskelijoille korkeakoulututkinnon suorittaminen oli lisäksi merkinnyt lapsuudenkodin kulttuurisista juurista irtautumista.

Opiskelijan lähipiirissä akateemista koulutust ja aikuisikäisenä kouluttautumista ei ole aina välttämättä edes pidetty kovin suuressa arvossa. Aikuisena opiskelua on saatettu pitää pikemminkin "oikean työn" vieroksumisena ja vastuun välttelynä. Sen vuoksi aikuisiässä yliopistossa opiskeleminen vo herättää opiskelijoissa itsessäänkin ristiriitaisia tuneita: yhtälttä koetaan ylpeyttä akatemisoitumisesta toisaalta syyllisyyttä monista muista syistä.

Toisen mahdollisuuden käyttäjien kertomukset tuovat esiin sen, että koulutusmahdollisuuksien eriarvoistuminen alkaa varhain, koulutustien alkupäässä tai ennen kouluikää. Sen vuoksi koulutuksellise tasa-arvon toteutumista ei voi edistää pelkästään koulutuspoliittisin keinoin, vaan myös perhe- ja sosaalipoliittiset päätökset ovat keskeisiä. Yhteiskunnan tukea tarvitaan erityisesti silloin, kun vanhemmilla ei ole voimavaroja tukea lastaan riittävästi. Koulutusvalintojen sattumanvaraisuus ja tiedon puute ovat usein sidoksissa kodin vähäisiin resursseihin, joten jo yläkoulussa olisi panostettava erityisesti henkilökohtaiseen opinto-ohjaukseen ja urasuunnitteluun.

Nopeutta ja tehokkuutta korostavassa yhteiskunnassa tulisi lisäksi muistaa, että kaikkien koulutuspolku ei ole suoraviivainen ja katkeamaton. Uudet valinnat ja koulutukselliset suunnan muutokset eivät välttämättä merkitse virheiden tai epäonnistumisten korjaamista vaan voivat olla osa onnistunutta koulutuspolkua.

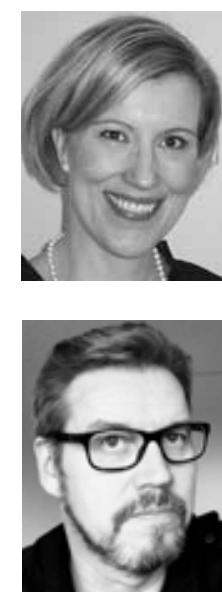

KT, VTM, yliopistotutkija Turun yliopisto

ARKKU VANTTAJA

$K T$, dosentti, yliopistotutkija Kasvatustieteiden laitos, CEL Turun yliopisto

LÄHTEET

Archer, L. \& Hutchings, M. (2000). 'Bettering yourself'? Discourses of risk, cost and benefit in ethnically diver-
se, young working-class non-participants' constructions of higher education. Bitish Jount' of Sociology fociology

Askham, P. (2008). Context and identity: exploring adult learners' experiences of higher education. Journal of Further and Higher Education 32 (1), 85-97.

Bahr, P. R. (2010). The bird's eye view of community colleges: A behavioral typology of first-time students based on cluster analytic classification. Research in Higher Education 51, 724-749.
Bahr, P. R. (2011). The use of cluster analysis in typological research on community college students. New Directions for Institutional Research. Bielby, R. \& Houches to Understand College Student Experiences and Outcomes, 67-81.

Bourdieu, P. (1986). The Forms of Capital. Teoksessa J. Richardson (toim.) The Handbook of Theory and Research for the Sociology of Education. New York: Grench Press, 241-258.

Bourdieu, P. \& Wacquant, L. (1995). Refleksiiviseen sosiologiaan. Tutkimus, käytäntö ja yhteiskunta. Joensuu. Joensuu University Press. 
Haltia, N., Jauhiainen, A. \& Isopahkala-Bouret, U. (2017). Ei-ylioppilastaustaiset korkeakouluopiskelijat. Eurostudent VI -tutkimuksen artikkelisarja. Opetus- ja kulttuuriministeriön julkaisuja 2017: 28.

Halttunen, N. (2007). Aikuisten hakeutuminen yliopistojen tutkinto-opiskelijoiksi. Aikuiskasvatus 27 (1), 4-14.

Hodkinson, P. \& Sparkes, A. C. (1997). Careership: A sociological theory of career decision making. British Journal of Sociology of Education 18 (1), 29-44.

Holmegaard, H. T., Ulriksen, L. M. \& Madsen, L. M. (2014). The process of choosing what to study: A longitudinal study of upper secondary students' identity work when choosing higher education. Scandination
Journal of Educational Research 58 (1), 21-40.

Huberty, C. J., Jordan, E. M. \& Brandt, W. C. (2005). Cluster analysis in higher education research. Teoksessa J. C. Smart (toim.) Higher Education: Handbook of Theory and Research Vol. 20, 437-457.

Jenkins, A. (2017). Who upgrades to higher level qualifications in midlife? British Journal of Educational Studies 66 (2), 1-24.

Järvinen, T. (1999). Peruskoulusta toisen asteen koulutukseen. Siirtymävaiheen kokemukset ja koulutusvalintojen taustatekijät oppilaiden kertomina. Turku: Turun yliopisto.

Käyhkö, M. (2014). Kelpaanko? Riitänkö? Kuulunko? Työläistaustaiset naiset, yliopisto-opiskelu ja luokan kokemukset. Sosiologia 51 (1), 4-20

Marks, A., Turner, E. \& Osborne, M. (2003). 'Not for the likes of me': The overlapping effect of social class and gender factors in the decision made by adults not to participate in higher education. Journal of Further and Higher Education 27 (4), 347-364.

Mercer, J. (2007). Re-negotiating the self through educational development: Mature students' experiences. Research in Post-Compulsory Education 12 (1), 19-32.

Moisio, J. (2017). Eurostudent V (2012-2015) -tutkimus. Mitä Eurostudent kertoo opiskelijoista, opinnoista ja opiskelusta 2010-luvun Euroopassa? http://blogs. helsinki.fi/hegompage/files/2015/02/Curostudent-V 2012-2015-tuloksia-opiskelusta-ja-opiskelijoista.pd

Moore, E. (2000). Aikuisena yliopistossa. Yliopisto-opiskelijoiden ikärakenne ja 30 vuotta täyttäneiden opiskelijoiden elämänkulku. Sosiologian tutkimuksia, Joensuu: Joensuun yliopisto.

Moore, E. (2003). Pitkä opintie. Aikuisiällä suoritettu yliopistotutkinto ja koulutuksellisen elämänkulun muutos. Joensuu: Joensuun yliopiston yhteiskuntatieteellisiä julkaisuja nro 61

Muhonen, R. (2013). "Työläisten lapsista ei herroja kouluteta" Kokemuksia opinteillä etenemisestä itsenäisyyden alun Suomessa. Sosiologia (50) 1, 29-45.
Nori, H. (2011). Keille yliopiston portit avautuvat? Tutkimus suomalaisiin yliopistoihin ja eri tieteenaloille valikoitumisesta 2000-luvun alussa. Turun yliopiston julkaisuja, C: 309

Nummenmaa, L. (2004). Käyttäytymistieteiden tilastolliset menetelmät. Helsinki: Tammi

O'Boyle, N. (2014). Front row friendships: Relational dialectics and identity negotiations by mature students at University. Communication Education 63 (3), 169-191.

OKM (2016). Valmiina valintoihin. Ylioppilastutkinnon parempi hyödyntäminen korkeakoulujen opiskelijava-

OKM (2017). Korkeakoulujen opiskelijavalintojen kehittämisen toimenpiteet 2017-2020. https://minedu. fi/documents/1410845/4154572/Korkeakoulujenopiskelijavalintojen+kehitt\%C3\%A4misen+toimen piteet_20170817.pdf/09af5b53-2658-4866-8a4ec6aeda33be84/Korkeakoulujen+opiskelijavalintojen + kehitt\%C3\%A4misen+toimenpiteet_20170817.pdf. pdf (9.10.2018).

O'Shea, S. (2014). Transitions and turning points: Exploring how first-in-family female students story their transitions to university and student identity formation. International Journal of Qualitative Studies in Education (27) 2, 135-158.

Read, B., Archer, L. \& Leathwood, C. (2003). Challenging cultures? Student conceptions of 'belonging' and 'isolation' at a post-1992 University. Studies in Higher ion 28 (3), 261-277

Reay, D. (2003). A risky business? Mature working class women students and access to higher education. Gender and Education 15 (3), 301-318.

Rinne, R., Haltia, N., Nori, H. \& Jauhiainen, A. (2008). Yliopiston porteilla. Aikuiset ja nuoret hakijat ja sisäänpäässeet 2000-luvun alun Suomessa. Kasvatusalan tutkimuksia 36. Suomen kasvatustieteellinen seura.

Vanttaja, M. (2002). Koulumenestyjät. Tutkimus laudaturyliop (2002) Koulums ja työuista. Kasvasusaln tutkimuksia 8 . Suomen kasuaustistellinen seura.

Vipunen (2017). Yliopistojen hakeneet ja paikan vastaanottaneet. https://vipunen.fi/fi-fi/_layouts/15/xlview aspx?id=/Ii-fi/Raportit/Haku-\%20ja\% 20valintatiedot\% $20 \%$ 20korkeakoulu\% $20-\% 20$ yo\% $20 \% 20$

Vipunen (2018). Yliopistokoulutuksen opiskelijat.

https://vipunen.fi/fi-fi/_layouts/15/xiviewer.aspx?id=/

fi-fi/RaportitYliopistokoulutuksen\%20opiskelijat-

n\%C3\%A4k\%C3\%B6kulma-vuosi.xlsb (28.8.2018).

\title{
Osaaminen ja kilpailukyky YAMK-tutkinnon suorittaneiden suhteellisen työmarkkina-aseman määrittäjinä
}

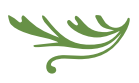 \\ Ylemmän ammattikorkeakoulututkinnon (YAMK) suorittaneet kokevat \\ tutkintonsa kilpailukyvyn heikommaksi kuin maisterin tutkinnon. \\ Sen sijaan osaamistaan he pitävät vahvana sukupuoleen tai \\ koulutusalaan katsomatta. Miehet ja erityisesti tekniikan alalta \\ valmistuneet arvioivat tutkintonsa kilpailukyvyn muita vahvemmaksi.
}

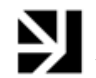
työmarkkinoilla käytävään kilpailuun ja menestyä siinä (Brown, Hesketh \& Williams 2003).

Koulutusvaatimukset ovat kasvaneet yleisen koulutustason noustessa. Korkeakoulutettujen määrä työmarkkinoille tulevissa nuorissa ikäpolvissa on lisääntynyt viime vuosikymmenten aikana. Korkeakoulututkinnon suorittaneiden osuu 25-34-vuotiaista on Suomessa jo yli 40 prosenttia
(OECD 2017), ja kansallisen korkeakoulutuksen ja tutkimuksen vision tavoite on, että korkeakoulutettujen osuus on tulevaisuudessa yli 50 prosenttia ikäluokasta (OKM 2017)

Korkeakoulututkinnon hankkiminen on tullut mahdolliseksi yhä useammalle suomalaiselle sen jälkeen, kun yliopistolaitoksen rinnalle luotiin ammattikorkeakoulujärjestelmä vuonna 1995. Lisäksi vuonna 2005 vakinaistetut ylemmät ammattikorkeakoulututkinnot, YAMK-tutkinnot, mahdollistivat ammattikorkeakoulututkinnon suorittaneille 
väylän jatkaa opintoja maisteritasoisiin ylempiin korkeakoulututkintoihin saakka. Ammattikorkeakoulujärjestelmän syntyminen loi samalla aivan uudenlaisen kilpailuasetelman suomalaisille työmarkkinoille, sillä työnhakutilanteessa voi samaa työpaikkaa tavoitella sekä ammattikorkeakoulusta että yliopistosta valmistuneita.

Yliopisto- ja ammattikorkeakoulusektoreiden välinen kilpailuasetelma on lähtökohtana artikkelimme kysymyksenasettelussa. Olemme kiinnostuneita siitä, minkälaiset tekijät määrittelevät korkeakoulututkintojen ja niitä vastaavien ammatillisten asemien välistä suhdetta ja sitä kautta eri tutkinnon suorittaneiden työmarkkina-asemaa.

Korkeakoulutettujen työllistymistä koskevissa tutkimuksissa on yleisesti tarkasteltu sitä, millaisiin ja minkä tasoisiin ammatillisiin tehtäviin tietyn koulutuksen ja tutkinnon suorittaneet sijoittuvat. Kysymyksenasettelu on usein kuvastanut kiinnostusta siihen, työllistyvätkö korkeakouluista valmistuneet omaa koulutustaan vastaaviin työtehtäviin. Koulutusalojen vertailussa on kiinnostanut, millaisiksi korkeakoulutettujen keskinäiset suhteet koulutusja ammatillisten alojen hierarkioiden kautta tarkasteltuna määrittyvät. (esim. Kirjalainen 2010; Sainio, Carver \& Kangas 2017; Stenström, Laine \& Valkonen 2005; Varamäki, Heikkilä \& Lautamaja 2011; ks. uraseurannat.wordpress.tamk.fi.)

Monet työmarkkinoita ja kansallista korkeakoulujärjestelmää koskevat tekijät vaikuttavat siihen, millaisiksi yksittäisen tutkinnon suorittamisen merkitys ja sen myötä saavutettava työmarkkina-asema muodostuvat (Ojala \& Isopahkala-Bouret 2015). Meitä kiinnostavat erityisesti korkeakoulusektoreiden suhde ja vertailuasetelma tutkinnon suorittaneiden työmarkkina-asemien muotoutumisessa: mitkä tekijät määrittävät suhteellista työmarkkinaasemaa?

Analysoimme YAMK-tutkintoja suorittaneiden näkemyksiä asemastaan suomalaisilla työmarkkinoilla suhteessa samaa koulutustasoa vastaavan maisterin tutkinnon suorittaneisiin. Tarkastelemme myös sukupuolen ja koulutusalan ja analysoimme niiden merkitystä tutkinnon suorittaneiden arvioihin työmarkkina-asemansa muodostumisessa.
Tutkimuskysymyksemme ovat seuraavat:

1. Miten YAMK-tutkinnon suorittaneet määrittävät omaa suhteellista asemaansa työmarkkinoilla?

2. Miten sukupuoli ja koulutusala ovat yhteydessä YAMK-tutkinnon suorittaneiden arvioihin suhteellisesta työmarkkina-asemastaan?

Empiirisenä aineistona käytämme YAMK-tutkinnon suorittaneille suunnattua kyselyä $(\mathrm{N}=1274)$. Vastaajilla on omaa kokemusta siitä, millä tavalla tutkintoon on työmarkkinoilla suhtauduttu: minkälaisia työtehtäviä se on avannut, miten hyvin sen avulla on menestynyt työnhakutilanteissa ja minkälaista ura- ja palkkakehitystä se on mahdollistanut?

Tutkimuksemme käsitteellistää uudella tavalla aiempaa YAMK-tutkinnon ja maisterin tutkinnon välisestä vertailuasetelmasta tehtyä tutkimusta (esim. Ojala 2017; Ojala \& Isopahkala-Bouret 2015; Isopahkala-Bouret 2014; Isopahkala, Rantanen, Raij \& Järveläinen 2011; Rantanen, Isopahkala-Bouret, Rai \& Järveläinen 2010; Galli \& Ahola 2010). Aiempi tutkimus on keskittynyt pääasiassa laadulliseen tarkasteluun. Analyysimme tuloksena mallinnamme tutkinnon suorittaneiden suhteellisen työmarkkina-aseman perustavia osatekijöitä tilastollisen aineiston avulla. Tällä tavalla aihetta ei ole aikaisemmin tutkittu.

\section{KORKEAKOULUTUS PÄÄOMANA JA}

\section{PÄÄSYLIPPUNA HYVÄÄN ASEMAAN}

Lähestymme korkeakoulututkintojen ja niitä vastaavien työmarkkina-asemien välistä suhdetta kahden vaihtoehtoisen teoreettisen näkökulman avulla Korkeakoulututkinnon hankkiminen voidaan ensinnäkin nähdä investointina inhimilliseen pääomaan (Schultz 1961; human capital theory). Inhimillistä pääomaa tutkinut Theodore W. Schultz (1961) määrittelee inhimillisen pääoman koulutuksen yhteydessä saaduiksi yksilön hyödyllisiksi tiedoiksi ja taidoiksi. Kouluttautumalla saavuttaa sellaista osaamista, jok merkittävästi lisää työntekijän tuottavuutta ja josta työnantajat ovat kiinnostuneita ja valmiita maksamaan. Tutkinnon suorittaminen määrittyy näin välineeksi lisätä työllistyvyyttä ja kilpailukykyä työmarkkinoilla (ks. myös Tuominen 2013).

\section{Koulutuksen}

PÄTEVÖITTÄMÄLLÄ

ASIANTUNTIJALLA ON

AMMATILLISTA ARVOVALTAA,

JOTA MAALLIKOLLA EI OLE.

Yksilö investoi inhimilliseen pääomaan edistääkseen uraansa ja saadakseen palkan kautta koulutusinvestoinnilleen hyvän tuoton. Koulutukseen hakeutuessaan yksilö tekee sijoituksen, jonka toivoo realisoituvan parempina palkkatuloina tai korkeampana ammatillisena statuksena tai molempina. YAMK-koulutukseen hakeutumisen syitä ovatkin man osaamisen kehittämisen ohella olleet muun muassa oman kilpailukyvyn ja työmarkkina-aseman vahvistaminen, mahdollisuus edetä uralla, yhä vaativammat työtehtävät, yhä parempi palkka ja tutkinnon tuoma status (esim. Ojala 2017; Ojala \& Ahola 2008, 88-93)

nhimilliseen pääomaan perustuva selitys korkeakoulutettujen suhteellisen aseman muotoutumisest nojaa oletukseen yhteiskunnan ja työmarkkinoiden muutoksesta ja teknologian kehityksestä. Suorittavan työn osuus suomalaisilla työmarkkinoilla on pienentynyt, ja uuden työn vaatimukset edellyttävät yh monimutkaisempaa tietotaitoa. Korkeakoulutuksesta on tullut enenevässä määrin edellytys työmarkkinoilla tarvittavien tietojen ja taitojen hankkimiseen. Mitä paremman osaamisen kouluttautumisen avulla pystyy hankkimaan, sitä paremman ammatillisen aseman voi työelämässä saavuttaa. Yksinkertaistaen esitettyn korkeakouluista valmistuneiden välinen kilpailu on silloin ennen kaikkea kilpailua parhaasta inhimillisestä pääomasta. (Becker 1962; Tomlinson 2008.)

Korkeakoulututkintojen ja niitä vastaavien ammatillisten asemien välistä suhdetta voidaan vaihtoehtoisesti tarkastella weberiläisen koulutuskredentialismin (credentialist theory) (esim. Collins 1979) näkökulmasta. Tällöin huomio kiinnittyy tutkintojen kulttuuriseen ja poliittiseen merkitykseen.
Korkeakouluinstituution historiallisten ja kulttuuristen käytäntöjen kautta tutkinnoista on muodostunut legitiimejä sisäänpääsyn ja poissulkemisen välineitä, joilla säädellään sitä, ketkä pääsevät työmarkkinoill mihinkin töihin ja tehtäviin (Bills 2004). Korkeakoulututkinnot ovat avainasemassa kilvoiteltaessa parhaista ammatillisista ja yhteiskunnallisista asemista sillä korkeakoulututkinnon suorittaneet ovat aina etulyöntiasemassa työmarkkinoilla suhteessa niihin joilla oikeanlaista tutkintoa ei ole.

Koulutuskredentialistisessa lähestymistavassa tutkinnoilla on tietynlainen arvo itsessään. Ne ovat abstraktioita opiskelujen aikana hankitusta sisällöllisestä tietämyksestä ja osaamisesta, jota kukaan ulkopuolinen tai ammatillisissa hierarkioissa alempana oleva ei voi kyseenalaistaa (Brown 2001). Koulutuksen pätevöittämällä lääkärillä, juristilla ja opettajalla on ammatillista arvovaltaa, jota maallikoilla ei ole. Työnantajat käyttävät tutkintoja ainakin kahdessa abstraktissa merkityksessä: Ensinnäkin tutkintovaatimukset karsivat ja rajaavat potentiaalisten työnhakijoiden määräa. Toiseksi ne ilmentävät työnhakijoiden luotettavuutta (trustworthiness); voidaan ikään kuin turvallisesti olettaa, että korkeakoulutetut hakijat ovat sosiaalistuneet oikeanlaiseen professionaaliseen kulttuuriin (Brown 2001).

Oleellista on siis tutkintokoulutuksen tuottaman osaamisen rinnalla kysyä, millaisia kulttuurisia arvostuksia tiettyihin tutkintoihin kiinnittyy. Mitä ne symboloivat? Kuinka hyvin ne toimivat pääsylippuin työelämän ja yhteiskunnan arvostetuille paikoille? Korkeakoulutettujen asemaan vaikuttavat tutkintojen hyvä maine ja arvostus mutta myös ammatillisten pätevyysvaatimusten ja lainsäädännön avulla niille tuotetut monopoliasemat (Bills 2004; Brown 2001) Rakenteellisilla seikoilla kuten korkeakoulusektoreden ja koulutusalojen välisillä eroilla, on myös vaikutusta tutkinnon suorittaneiden asemaan ja suoritetun tutkinnon arvostukseen (Isopahkala-Bouret 2018).

\section{YAMK-TUTKINTO SUOMALAISESSA}

\section{KORKEAKOULUJÄRJESTELMÄSSÄ}

YAMK-tutkintojen ja maisterin tutkintojen kesk näistä asetelmaa määrittävät lähtökohtaisesti niiden 
YAMK-TUTKINTO ON

KÄYT $\ddot{A N N O ̈ N L A ̈ H E I N E N ~ J A ~}$

TYÖELÄM ÄLÄHTÖINEN.

erilaiset asemat koulutusjärjestelmässä. Suomalaisen korkeakoulujärjestelmän olennainen piirre on duaalimallin mukainen jako kahteen rinnakkaiseen sektoriin: perinteiseen, akateemiseen yliopistoon ja ammatillisesti suuntautuneeseen ammattikorkeakouluun. Kummallakin nähdään olevan omat tehtävänsä ja profiilinsa, mikä vaikuttaa olennaisesti eri sektoreilla suoritettavien tutkintojen asemaan ja luonteeseen. Ammattikorkeakoulut ovat käytännön työelämään, professionaaliseen toimintaan ja aluekehitystehtävään sitoutuneita, pääosin monialaisia ja alueellisia korkeakouluja, kun yliopistoissa tehdään tieteellistä tutkimusta ja annetaan tutkimukseen perustuvaa ylintä opetusta (OPM 2009)

Duaalimallin dynamiikka on ohjannut voimakkaasti tutkintojärjestelmän kehitystä. Kun ammattikorkeakoulut 1990-luvulla perustettiin, ammattikorkeakoulun perustutkinnosta tuli alempi korkeakoulututkinto. Korkeakoulutettujen määrä työmarkkinoilla alkoi lisääntyä, ja kilpailu työmarkkinoilla kiristyi. Ammattikorkeakoulututkinnon suorittaneet eivät pystyneet kilpailemaan yliopistotutkinnon suorittaneiden kanssa, mikä osaltaan johti keskusteluun ammattikorkeakoulujen jatkotutkinnoista. Niiden suunnittelussa keskeiseksi periaatteeksi tuli, että jatkotutkintojen tuottaman kelpoisuuden julkisiin virkoihin ja tehtäviin tuli olla sama kuin yliopistojen maisterin tutkintojen (Pratt ym. 2004).

Valmisteluprosessia luonnehti ristiriitojen sävyttämä keskustelu, jossa erityisesti yliopistoissa oltiin jatkotutkintoja kohtaan kriittisiä (Herranen 2003, 9; Ojala \& Ahola 2008, 18). Ne katsoivat, että ylemmät korkeakoulututkinnot kuuluivat vain yliopistoihin. Myös monet työelämän edustajat suhtautuivat jatkotutkintoon ja sen tarpeeseen epäilevästi. Tutkinnon vastustajat vetosivat muun muassa status- ja rahoituskysymyksiin ja katsoivat, että koulutustarpeisiin voitiin vastata jo olemassa olevilla koulutusratkaisuilla.
Ammattikorkeakoulun edustajat puolestaan esittivät jatkotutkintojen tarpeen perusteena muun muassa korkeakoulumarkkinoiden kansainvälistä kilpailukykyä ja vertailtavuutta (Ojala 2017). Jatkotutkintokoulutuksen puolustajat eivät suoranaisest perustelleet tutkintoja ammattikorkeakoulujen statuksella, mutta on selvää, että tutkintojen merkitys voidaan vahvasti nähdä juuri ammattikorkeakouluen uskottavuuden lisääjänä ja korkeakoulustatuksen vahvistajana (Isopahkala-Bouret 2018; Herranen 2003,9)

Valmistelua seuranneen kokeiluvaiheen jälkeen ammattikorkeakoulujen jatkotutkinnot vakinaistettiin kesällä 2005 (Neuvonen-Rauhala 2009; Ojala \& Ahola 2008). Samalla luovuttiin 'jatkotutkinnon' käsitteestä, jotta se ei sekoittuisi yliopistoissa suoritettaviin jatkotutkintoihin, ja siirryttiin käyttämään ylemmän ammattikorkeakoulututkinnon (YAMK) nimikettä.

Lain tultua voimaan ensimmäiset vakinaiset YAMK-tutkintoon johtavat koulutusohjelmat käynnistettiin silloisen opetusministeriön päätöksillä niilä koulutusaloilla ja niissä ammattikorkeakouluissa jotka olivat olleet mukana jatkotutkintokokeilussa. (OKM 2011.) Sittemmin YAMK-tutkinnot ovat kehittyneet merkittäväksi ammattikorkeakoulututkinnon jälkeiseksi ylempään korkeakoulututkintoon johtavaksi jatkokoulutusväyläksi (Arene 2016), ja tutkintoja suoritetaan yhä enemmän. Kun esimerkiksi vuonna 2014 suoritettiin 2115 tutkintoa, vuonn 2017 tutkintojen määrä oli 2 756. (Vipunen 2018 ks. myös SVT 2018.)

YAMK-tutkinnot ovat käytännönläheisiä ja työelämälähtöisiä aikuiskoulutustutkintoja. Tutkintokoulutukseen hakijalta edellytetään kolmen vuoden työkokemusta ammattikorkeakoulu- tai korkeakoulututkinnon jälkeen, mikä on myös rakentanut tutkinnoille omaleimaista luonnetta (Panhelainen \& Varmola 2017). Tosin kolmen vuoden työkokemusvaatimusta ollaan laskemassa kahteen vuoteen (Arene 2018). Lsäksi tutkinto suoritetaan tyypillisesti työn ohessa, el tutkinnon suorittajat ovat valmistuessaan jo valmiiks työelämässä (esim. Ojala \& Ahola 2008; Ojala 2017).

Tutkinnolla on vahva yhteys oman työn kehittämiseen, ja tarkoitus on, että tutkinto vastaa työelämän uudistuvia osaamistarpeita ja -vaatimuksia sek vahvistaa työelämän osaamisperustaa (Rantanen \& Järveläinen 2010).

YAMK-tutkinnon suorittaneiden työllisyysaste on hyvä (esim. Vipunen 2018). Vaikka YAMK-tutkinnot ja maisterin tutkinnot tuottavat julkiseen virkaan tai tehtävään saman kelpoisuuden (OPM 2009), YAMK-tutkinnon suorittaneiden pääsy ylempää korkeakoulutusta edellyttäviin asiantuntija- ja johtotehtäviin on kummallakin ollut haasteellista. (Isopahkala-Bouret 2014). Työnantajien on todettu arvottavan yliopistotutkinnon ja ammattikorkeakoulututkinnon suorittaneita eri tavoin. YAMK-tutkinnon suorittaneiden osaamisen tasoa pidetään yleisesti maisterin tutkinnon suorittaneita alhaisempana (IsopahkalaBouret ym. 2011; Rantanen ym. 2010; Ojala 2017) Maisterin tutkinnon perinteisen arvostuksen lisäksi YAMK-tutkinnon suorittaneiden altavastaaja-asemaa työmarkkinoiden rekrytointiasetelmissa on pitänyt yllä tutkinnon heikko tunnettuus (Ojala 2017; Ojala \& Isopahkala-Bouret 2015)

\section{TUTKIMUKSEN TOTEUTUS}

Empiirisenä aineistonamme on vuonna 2012 Webropol-sovelluksella kerätty YAMK-tutkinnon suorittaneille suunnattu kysely ( $\mathrm{N}=1274$, vastausprosentti $36^{1}$ ). Kysely käsitteli muun muassa tutkinnon suorittaneiden kokemuksia YAMK-tutkinnosta sekä heidän käsityksiään tutkinnosta ja sen merkityksestä työmarkkinoilla. Tutkimuksen perusjoukon muodostavat vuosina 2006-2012 YAMK-tutkinnon suorittaneet kaikilta ammattikorkeakoulun ${ }^{2}$ kahdeksalta koulutusalalta. Kyselyyn vastanneiden valmistumisesta oli siis kulunut alle vuodesta kuuteen vuoteen.

Yli 85 prosenttia vastauksista tuli niiltä, jotka olivat valmistuneet ammattikorkeakoulun kolmelt suurimmalta koulutusalalta: sosiaali- ja terveysalalta, tekniikan alalta ja liiketalouden alalta ${ }^{3}$. Vastaajista naisia oli 63 prosenttia ja miehiä 37 prosenttia. Heidän ikänsä vaihteli 28 ikävuodesta 66 ikävuoteen, kun keski-ikä oli 43 vuotta. Valtaosalla YAMK-tutkinnon suorittaneista oli aiempi ammattikorkeakoulututkinto. Lisäksi lähes 75 prosenttia oli suorittanut muitakin tutkintoja, kuten toisen asteen, opisto- tai korkea-asteen ammatillisen tutkinnon. Erilainen täydennys- ja lisäkouluttautuminen oli myös yleistà.

Rajaamme empiirisen aineistomme analyysin kyselylomakkeen osioon, joka käsittelee YAMK-tutkintoa työmarkkinoilla suhteessa maisterin tutkintoon Tutkinnon suorittaneet arvioivat YAMK-tutkintoa ja sen asemaa työmarkkinoilla verrattuna maisteri tutkintoon yhdeksästä väittämästä koostuneella viisiportaisella asteikolla: $1=$ täysin eri mieltä [-- $5=$ täysin samaa mieltä.

Likert-asteikolliseen kysymykseen pohjautuva aineisto analysoitiin käyttäen prosenttijakaumia, keskiarvoja, pääkomponenttianalyysia (Principal Component Analysis, PCA), konfirmatorista faktorianalyysia (Confirmatory Factor Analysis, CFA) ja yksisuuntaista varianssianalyysia.

Faktorianalyyseja käytettiin keinona löytää summamuuttujat. Tarkoitus ei siten ollut tyytyä pelkästään väittämien sisällölliseen ryhmittelyyn vaan tehd ryhmittely tilastollisen tarkastelun avulla. Pääkomponenttianalyysin avulla etsitään suuren muuttujajoukon keskeltä muuttujien yhteistä vaihtelua ja muodostetaan muuttujista tulkittavissa olevia ryhmiä el näin vähennetään muuttujien määrää (Metsämuuronen 2009, 649). Pääkomponentin faktorirakenne varmistettiin konfirmatorisella faktorianalyysilla. Se on teorialähtöinen analyysimenetelmä, jossa tutkijalla on jo ennen analyysin suorittamista teoriaan perustuva oletus aineiston faktorirakenteesta. Näin saatiin testattua mallin yhteensopivuus aineiston kanssa. (ks. Ojala 2017, 70-71.)

\section{YAMK-TUTKINNON SUORITTANEIDEN ASEMAA}

\section{TYÖMARKKINOILLA MÄÄRITTÄVÄT TEKIJÄT}

Uusien tutkintojen asemoituminen työmarkkinoille on usein haasteellista. Koulutuksen työmarkkinarelevanssi korostuu siinä, miten YAMK-tutkinnon suorittaneet onnistuvat raivaamaan osaamiselleen paikkaa työelämän tehtävärakenteissa, Leena Viinamäki ja Anne Pohjola $(2016,92)$ toteavat He ovat tutkineet sosionomin YAMK-tutkinnon suorittaneiden koulutus- j työmarkkina-asemaa. Tutkinnon suorittaneiden asema märittyy pitkälti sen mukaan, kuinka työnantajat otaksuvat tutkinnon edustavan esimerkiksi tietynlaista osaamista ja tietynlaisiin tehtäviin pätevöitymistä. 


\begin{tabular}{|l|r|r|r|}
\hline Väittämä & $\begin{array}{r}\text { tai täysin samaa } \\
\text { mieltä } \\
\%\end{array}$ & $\begin{array}{r}\text { Eikä ei samaa } \\
\text { eiri mieltä } \\
\%\end{array}$ & $\begin{array}{r}\text { Jokseenkin } \\
\text { tai täysin } \\
\text { eri mieltä } \\
\%\end{array}$ \\
\hline $\begin{array}{l}\text { Työnantajat tuntevat YAMK-tutkinnon maisterin } \\
\text { tutkintoa huonommin }\end{array}$ & 90,1 & 6,4 & 3,5 \\
\hline $\begin{array}{l}\text { YAMK-tutkintoa arvostetaan työmarkkinoilla } \\
\text { maisterin tutkintoa vähemmän }\end{array}$ & 78,3 & 16,6 & 5,1 \\
\hline $\begin{array}{l}\text { YAMK-tutkinnon suorittaneilla on mahdollisuus } \\
\text { toimia maisterien kanssa samantasoisissa } \\
\text { työtehtävissä }\end{array}$ & 76,0 & 11,9 & 1,0 \\
\hline $\begin{array}{l}\text { YAMK-tutkinnon suorittaneiden työelämäosaaminen } \\
\text { on maistereita vahvempi }\end{array}$ & 71,9 & 19,3 & 8,7 \\
\hline $\begin{array}{l}\text { Työnhakutilanteessa YAMK-tutkinnon suorittaneet } \\
\text { häviävät maistereille }\end{array}$ & 61,7 & 28,3 & 10,0 \\
\hline $\begin{array}{l}\text { YAMK-tutkinto tuottaa spesifisempää osaamista } \\
\text { kuin maisterin tutkinto }\end{array}$ & 60,4 & 26,7 & 12,9 \\
\hline $\begin{array}{l}\text { YAMK-tutkinto tuottaa samantasoista osaamista } \\
\text { kuin maisterin tutkinto }\end{array}$ & 58,9 & 23,4 & 17,8 \\
\hline $\begin{array}{l}\text { YAMK-tutkinnon suorittaneilla on maistereita } \\
\text { paremmat uralla etenemisen mahdollisuudet }\end{array}$ & 10,6 & 41,0 & 48,4 \\
\hline $\begin{array}{l}\text { YAMK-tutkinnon suorittaneet sijoittuvat paremmin } \\
\text { palkattuihin työtehtäviin kuin maisterit }\end{array}$ & 9,6 & 39,5 & 50,9 \\
\hline
\end{tabular}

Taulukko 1. YAMK-tutkinnon suorittaneiden näkemykset suhteellisesta asemastaan työmarkkinoilla (\%).

YAMK-tutkinnon suorittaneiden epävarma suhtautuminen työmarkkina-asemaansa näkyi aineistossamme, kun tarkastelimme, miten tutkinnon suorittaneet arvottivat tutkintojaan suhteessa maisterin tutkintoihin (taulukko 1). Tutkinnon suorittaneet olivat lähes yksimielisiä siitä, että työnantajat tuntevat YAMK-tutkinnon maisterin tutkintoa huonommin. Useimmat yhtyivät myös väitteeseen, että YAMKtutkintoa arvostetaan työmarkkinoilla maisterin tutkintoa vähemmän. YAMK-tutkinnon suorittaneiden uralla etenemistä ja palkkausta suhteessa maistereihin tutkinnon suorittaneet pitivät erityisen heikkona; puolet tutkinnon suorittaneista ei uskonut samantasoisiin mahdollisuuksiin.

Vastanneista vain lähes 60 prosenttia arvioi YAMKtutkinnon tuottavan samantasoista osaamista kuin maisterin tutkinto. Tästä huolimatta valmistuneet olivat sitä mieltä, että YAMK-tutkinnon suorittaneilla on mahdollisuus toimia maisterien kanssa samantasoisissa työtehtävissä, ja että tutkinnon suorittaneiden työelä- mäosaaminen on vahvempi kuin maistereiden.

YAMK-tutkintoihin perehtyneen Kristiina Ojalan $(2017,139)$ tutkimuksessa työnantajien arvioinnit olivat hyvin samankaltaisia. Työnantajat olivat erityisen epäileväisiä sen suhteen, että tutkinto tuottaisi maisterin tasoista osaamista (ks. myös Isopahkala-Bouret ym. 2011). Heistä vain kaksi prosenttia oli asiaa kuvaavan väittämän kanssa jokseenkin tai täysin samaa mieltä. Tämän voidaan nähdä ilmentävän työnantajien matalaa YAMK-tutkinnon nauttimaa arvostusta suhteessa maisterin tutkintoon.

Jatkoimme analyysiamme päkomponentti analyysilla (liite 1), joka tuotti oletuksen kahdesta faktorista. Analysoimme faktoreita edelleen Mplusohjelmalla. Tuloksena muodostimme YAMK-tutkinnon suorittaneiden suhteellista työmarkkina-asemaa kuvaavan CFA-mallin (kuvio 1). Se koostuu kahdesta elementistä - tutkinnon tuottamasta kilpailukyvystä ja osaamisesta - sekä näihin sisältyvistä väittämistä. Standardoidut faktorikertoimet kuvaavat elementtien vaikutusta eri tekijöihin. Esimerkiksi tutkinnon kilpailukyky selittää erityisen hyvin sitä, etta YAMK-tutkinnon suorittaneilla on maistereita paremmat mahdollisuudet edetä uralla.

YAMK-tutkinnon tuottama kilpailukyky muodostuu neliästä osatekijästä: 1) arvostus, 2) menestyminen työnhaussa, 3) uralla eteneminen ja 4) sijoittuminen palkattuihin työtehtäviin verrattuna maistereihin

Ratkaiseva merkitys on nimenomaan työnhakutilanteissa menestymisellä. Se, ketkä valitaan haluttuihin työtehtäviin ja miten tutkinnon suorittaneet asemoituvat keskenään työnhakujonossa, määrittä suoraan tutkintojen kilpailukykyä. Samalla pärjääminen työnhaussa yksittäisenä tekijänä on eniten tutkinnon yleistä arvostusta heijasteleva tekijä. Hieman toisenlainen kilpailutilanne on kilvoittelu ylennyksistä ja parhaiten palkatuista johtotehtävistä. Millaisin koetaan YAMK-tutkinnon suorittaneiden urakehitysmahdollisuudet suhteessa maistereihin?

Tutkinnon tuottama osaaminen on toinen tutkinnon suorittaneiden työmarkkina-asemaa määrittävä elementti. Se koostuu kolmesta osatekijästä. Ensimmäinen on YAMK-tutkinnon suorittaneiden työelämäosaaminen suhteessa maistereihin: koetaanko työelämälähtöisessä koulutuksessa osaamisensa hankkineiden YAMK-tutkinnon suorittaneiden työelämäosaaminen akateemisesta maisterin tutkinnoista valmistuneita vahvempana. Toiseksi osaaminen kuvaa YAMK-tutkinnon tuottaman osaamisen spesifisyyttä eli sitä, onko se jotain, jota muut tutkinnot eivät sellaisenaan tuota. Kolmantena osatekijänä on, onko YAMK-tutkinnon tuottama alan osaaminen samantasoista maisterin tutkintoon verrattuna eli koetaanko oma osaaminen yhtä vahvaksi kuin maistereiden osaaminen. (Kuvio 1 .)

Kaksi elementtiä, tutkinnon tuottama kilpailukyky ja tutkinnon tuottama osaaminen, korreloivat keskenään positiivisesti ja kohtalaisesti (kuvio 1). Toisin sanoen tutkinnolle voi muodostua kilpailukykya vain, jos se tuottaa haluttua osaamista. Tutkinnon täytyy olla työmarkkinoilla riittävän kilpailukykyinen jotta sen tuottama osaaminen tunnistetaan.

Tarkastelimme YAMK-tutkinnon suorittaneiden asemaa työmarkkinoilla suhteessa maisterei hin myös vertailemalla tutkinnon asemaa kuvaava kahta elementtiä, faktoreista muodostettujen summamuuttujien keskiarvoja keskenään. Tutkinnon suorittaneet arvioivat YAMK-tutkinnon tuottaman osaamisen (ka 3.77, kh .819) vahvaksi. Tutkinnon kilpailukyky (ka 2.22, kh .764) sen sijaan arvioitiin heikoksi.

Kuten aiempi tutkimus on osoittanut, YAMKtutkinnot ovat alusta alkaen olleet suomalaisilla työmarkkinoilla altavastaajan asemassa. Tämä on näkynyt eritoten tutkinnon arvostuksen ja tunnettuuden puutteena sekä yleensä työnantajien varautuneena suhtautumisena tutkintoon (Ojala 2017; Ojala \& Isopahkala-Bouret 2015). Myös YAMK-tutkinnon suorittaneiden sijoittumista työelämään tarkastelleiden Elina Varamäen, Tarja Heikkilän ja Marja Lautamajan (2011,112-113) tutkimuksessa YAMK-tutkinnon arvioitiin menestyvän työmarkkinoilla heikosti suhteessa maisterin tutkintoon.

Todennäköisesti vahvasti perinteinen maisterin tutkinto toimii työnantajille signaalina koulutuksen laadukkuudesta, statuksesta ja arvosta ja sen myötä maisterin tutkinnon suorittaneen kyvyistä ja osaamisesta (ks. Spence 1973). Maisterin tutkinnon suorittaneella oletetaan olevan tietynlaisia haluttuja ja arvostettavia ominaisuuksia, joita YAMK-tutkinnon suorittaneella ei ole (esim. Rantanen ym. 2010). Tutkinnon viestimä signaali vaikuttanee työnantajien rekrytointipäätöksiin ja käsityksiin tutkintojen välisestä suhteesta (Ojala 2017).

\section{SUKUPUOLITTAISET JA KOULUTUSALOITTAISET}

EROT YAMK-TUTKINNON ASEMAN MÄÄRITTÄJINÄ

Erityisesti kilpailukykyä tarkasteltaessa on tärkeä huomioida ammattikorkeakoulun koulutusaloilta valmistuvien erilaiset volyymit ja alojen sukupuolittuneisuus. Muun muassa tekniikan ala on miesvoittoinen, ja sosiaali- ja terveysalalla enemmistö puolestaan on naisia (ks. myös SVT 2018). Etenkin alojen sukupuolittuneisuus vaikuttaa tutkinnon suorittaneiden ura- ja palkkakehitykseen.

Sukupuoli ja koulutusala ovat työmarkkinoilla toimimista suuntaavia keskeisiä tekijöitä. Ne ovat myös monimutkaistavia tekijöitä silloin, kun tarkastellaan tutkinnon suorittaneiden asemaa työmarkkinoilla. $(\mathrm{p}<0.001)$ Miehet kokivat YAMK-tutkinnon kilpailukyvyn suhteessa maisterin tutkintoon selvästi naisia 


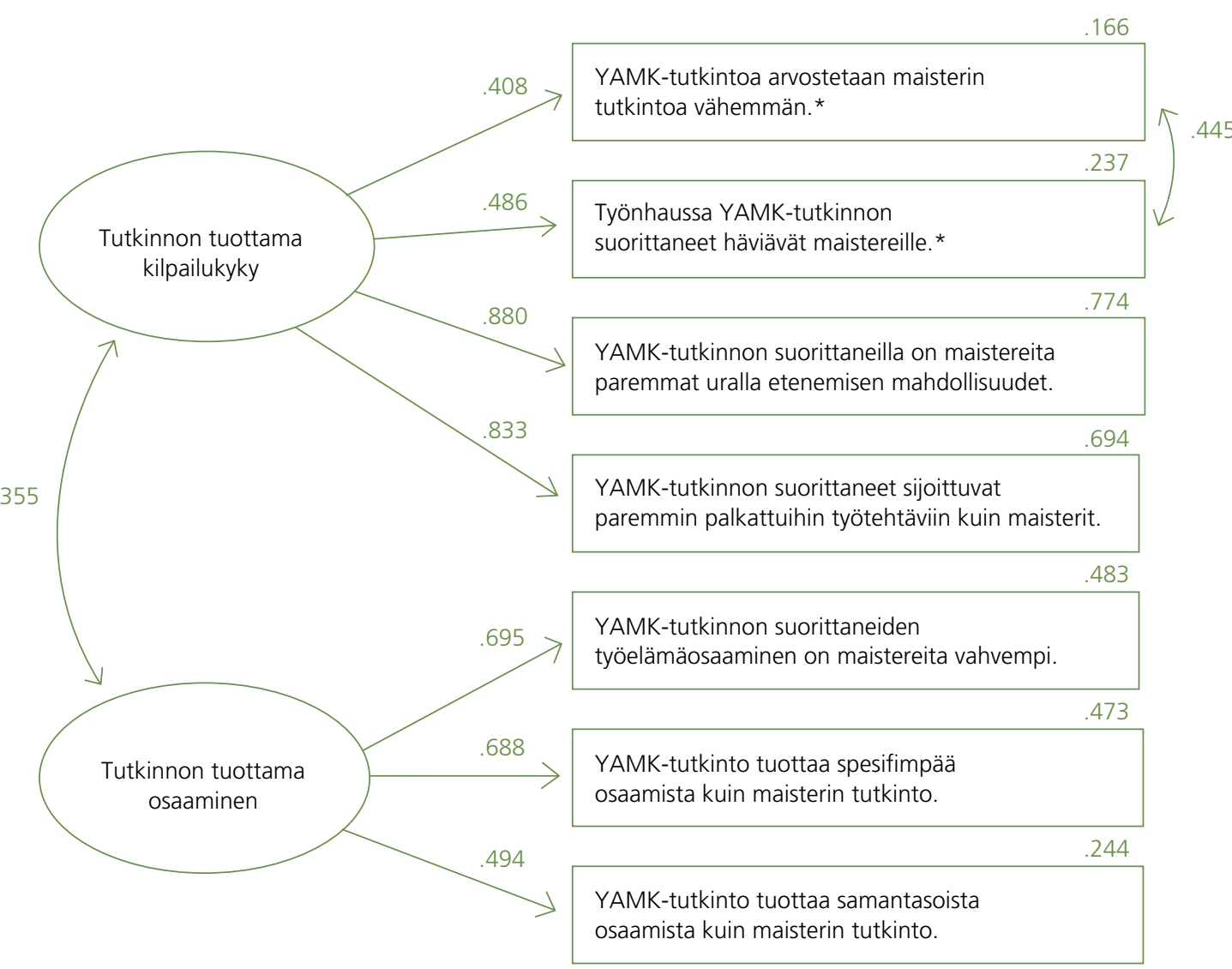

Kuvio 1. Valmistuneiden työmarkkina-asemaa määrittävät tekijät. CFA-malli YAMK-tutkinnon suorittaneiden asemasta työmarkkinoilla suhteessa maisterin tutkintoon. Mallin sopivuus: $\mathrm{N}=1274: \mathrm{X}^{2}=32.459, \mathrm{df}=12, \mathrm{p} .=.012, \mathrm{CFI}=.989$, $\mathrm{TLI}=.980, \mathrm{RMSEA}=.037, \mathrm{SRMR}=.033$.

* Väittämä käsitelty käänteisenà.

paremmaksi $(-0.231)$. Korkeakoulutuksen on todettu vahvistavan erityisesti miesten asemaa (esim. Naumanen 2002, 24-25; Vuorinen-Lampila 2016), ja miehet pääsevät naisia todennäköisemmin korkeampiin asemiin työelämässä (ks. Vuorinen \& Valkonen 2007, 141). Tutkinnon tuottama osaamisen suhde maisterin tutkintoon sen sijaan koettiin samalla tavalla riippumatta sukupuolesta5. (ks. Ojala 2017, 136.)

Koulutusalojen väliset erot tutkinnon tuottamassa kilpailukyvyssä olivat suuria $(\mathrm{F}(5)=20.50, \mathrm{p}<0.001$,), $(\mathrm{\eta} 2=.08)$. Erityisen suuria olivat $(\mathrm{p}<0.001)$ tekniikan ja liiketalouden sekä tekniikan ja sosiaali-ja terveysalan väliset erot, mutta myös matkailu- ja ravitsemisalan ja sosiaali- ja terveysalan sekä kulttuurialan ja sosiaali- ja terveysalan väliset erot olivat suuria $(\mathrm{p}<0.01)$. Vähemmän eroja $(p<0.05)$ oli liiketalouden ja sosiaalija terveysalan sekä luonnonvara-alan ja sosiaali- ja terveysalan välillä. Tutkinnon tuottamaa osaamista sen sijaan pidettiin vahvana kaikilla koulutusaloilla.

\section{(Taulukko 2.)}

Tekniikan alalla tutkinnon kilpailukyky suhteessa maisterin tutkintoon näyttäytyy siis muita vahvempana, erityisesti suhteessa liiketalouden alaan ja sosiaali- ja terveysalaan. Myös matkailu- ja ravitsemisalalta, kulttuurialalta, liiketalouden alalta ja luonnonvara-alalta valmistuneet kokivat tutkintonsa kilpailukyvyn sosiaali- ja terveysalalta valmistuneita paremmaksi.

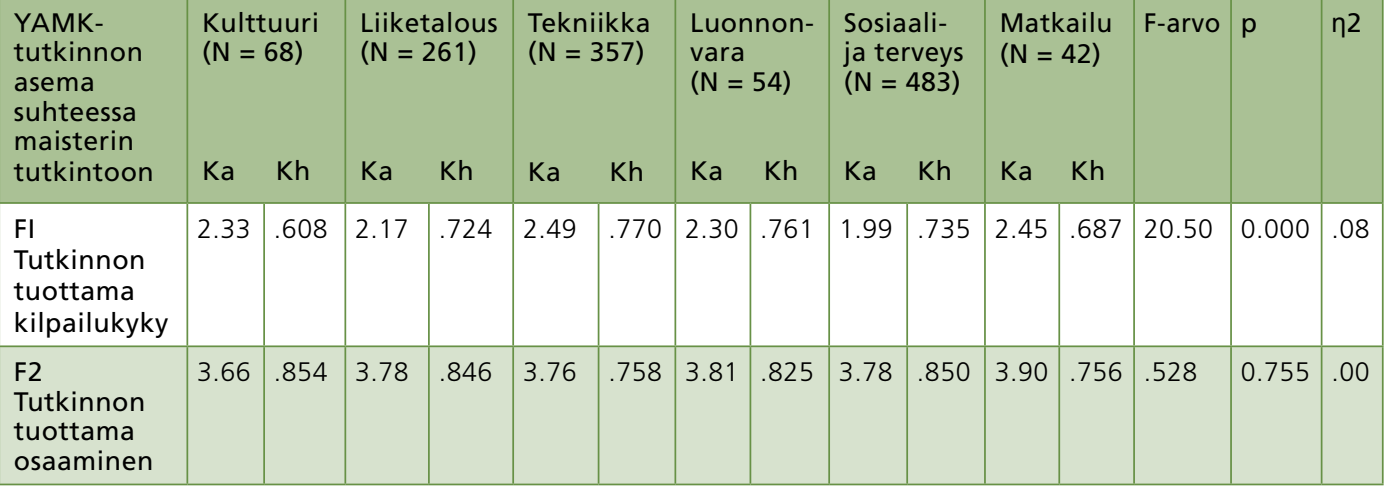

Taulukko 2. YAMK-tutkinnon asema työmarkkinoilla suhteessa maisterin tutkintoon koulutusaloittain ( 1 = täysin er mieltä [-] 5 = täysin samaa mieltä).

Mitkä tekijät sitten vaikuttavat kilpailukyvyn määrittymiseen eri aloilla? Sosiaali- ja terveysalalla koettu muita aloja heikompi kilpailukyky johtuu todennäköisesti siitä, että se koetaan vahvasti maistereita suosivaksi. Sosiaali- ja terveysalan ammatit ovat lailla säädeltyæä, alan työntekijät ovat tiettyyn tehtävään koulutettuja, eikä tutkinto anna oikeutta harjoittaa sosiaalityöntekijän ammattia (Laki 2015/817; ks. Rantanen \& Järveläinen 2010,132-133; Viinamäk \& Pohjola 2016,95). Myös palkkakehitys on työtehtävän mukainen. Lisäksi johtotehtäviä, esimiestehtäviä ja opetustehtäviä haettaessa maistereiden koetaan jättävän YAMK-tutkinnon suorittaneet toiseks (Ojala 2017). Muodolliset pätevyysvaatimukset voivat siis lukkiuttaa tutkinnon suorittaneiden etenemisen työmarkkinoilla.

Tekniikan alan työtehtäviä ei määritellä säädöksillä, eivätkä työasemat muodosta samalla tavalla hierarkiaa kuin sosiaali- ja terveysalalla. Omalla osaamisell voi enemmän vaikuttaa omiin työtehtäviin ja urakehitykseen. Muodolliset pätevyysvaatimukset ja säädetyt ammatit kehystävät näin selkeästi tutkintojen suorittaneiden suhteellista työmarkkina-asema (ks. Brown 2001). Tekniikan alan tutkinnon suorittaneiden kokemus tutkintonsa muita vahvemmasta kilpailukyvystä saattaa liittyä osaltaan myös alan miesvoittoisuuteen

\section{POHDINTA}

Olemme artikkelissamme mallintaneet sitä, mitkä tekijät rakentavat YAMK-tutkinnon suorittaneiden käsityksiä suhteellisesta asemastaan suomalaisilla työmarkkinoilla verrattuna maisterin tutkinnon suorittaneisiin. Saimme tulokseksi kaksi tutkinnon suorittaneiden asemaa määrittävää tekijää, jotka ovat 1) tutkinnon tuottama osaaminen ja 2) tutkinnon tuottama kilpailukyky. Osaaminen on työmarkkina-asemaa vahvistavaa ja kilpailukyky työmarkkinoiden parhaista työtehtävistä jollakin tavalla poissulkevaa.

Tutkinnon tuottama osaaminen on vahvasti sidoksissa inhimilliseen pääomaan (Schultz 1961), jota tutkinnon suorittaneet voivat hyödyntää työnhaussa, työnsä kehittämisessä ja työmarkkina-asemansa vahvistamisessa. YAMK-tutkinnon suorittaneet uskoivat vahvasti tutkintonsa tuottaneen sisällöllisesti arvokasta osaamista. Itseisarvoisesti arvioituna YAMK-tutkinnon suorittaminen ol ollut hyödyllinen ja kannattava investointi inhimilliseen pääomaan. Kouluttautumalla saavutetaan siten osaamista, joka lisää tutkinnon suorittaneiden tuottavuutta ja josta työnantajat ovat kiinnostuneita (ks. Schultz 1961). Osaamisen koettiin lisääntyneen riippumatta sukupuolesta ja koulutusalasta. YAMK-tutkinnon suorittaneiden osaamista vahvisti myös heille kertynyt työkokemus, jok toimii erityisenä kilpailuvalttina etenkin vastavalmistuneisiin maistereihin verrattuna (Ojala 2017). 
Tutkinnon suorittaneiden suhteellista työmarkkina-asemaa määrittävistä elementeistä tutkinnon kilpailukyky avautuu koulutuskredentialistisen näkökulman avulla (Collins 1979; Bills 2004; Brown 2001). Työmarkkina-asema on aina suhteellinen, eli sillä ei ole itseisarvoa. Hyväkään osaaminen ei pelkästään riitä, jos jollakulla toisella oletetaan olevan vielä parempaa osaamista.

YAMK-tutkinto ei toimi arvostettuna pääsylippuna parhaisiin ammatillisiin ja yhteiskunnallisiin asemiin, koska etulyöntiasema koetaan olevan maisterin tutkinnon suorittaneilla. Vaikka YAMK-tutkinto tuottaa inhimillistä pääomaa, se ei kasvata riittävän kilpailukykyistä pääomaa, joka realisoituisi työmarkkinoilla sen suorittaneiden työmarkkina-aseman kohoamisena (ks. Ojala 2017). Niinpä tarkastelumme keskeinen tulos on, että YAMK-tutkinnon suorittaneet arvioivat tutkintonsa kilpailukyvyn maistereihin verrattuna heikoksi. Syynä on se, että tutkintoa ei edelleenkään tunneta työmarkkinoilla kovin hyvin, eikä se ole sangen arvostettu (esim. Ojala 2017; Ojala \& Isopahkala-Bouret 2015; Ojala \& Ahola 2008, 144-145)

Tutkinnon suorittaneiden työmarkkina-asemaan vaikuttavat tutkinnon, koulutusalan ja sukupuolen lisäksi monet muut tekijät. Esimerkiksi työmarkkinarakenteet ja työllisyystilanne määrittävät korkeakoulutettujen työmarkkinoilla pärjäämistä. Aineistossamme sen suorittaneet kokivat kilpailukykynsä yleensä ottaen heikoksi. Siihen johtava koulutus voi kuitenkin YAMK-tutkintoa tarkastelleiden Kimmo Mäen, Liisa Vanhanen-Nuutisen ja Hannu Kotilan $(2017,174)$ mukaan usein tarjota valmistuneelle jopa nopeampaa työhön pääsyä ja parempaa alkupalkkaa kuin yliopistojen maisterikoulutus. Palkkaukseen vaikuttavat aiempi koulutus- ja työkokemus, joita molempia YAMK-tutkinnon suorittaneilla on usein enemmän kuin maisteritutkinnon suorittaneilla. Lisäksi työmarkkinat muuttuvat koko ajan

Kun YAMK-tutkinnot yleistyvät, voidaan olettaa, että niiden tunnettuus lisääntyy ja kilpailukykyisyys työmarkkinoilla paranee (Ojala \& IsopahkalaBouret 2015). Varsinkin kun työmarkkinoille tulee enemmän sellaisia työnantajia, joilla itsellään on
AMK-tutkintotausta, se parantaa tutkinnon suoritneiden asemaa työmark

YAMK-tutkinnon suorittaneiden työmarkkina-asemaa tulisikin tulevaisuudessa tarkastella pitkäkestoisesti tutkinnon suorittaneiden työurien kehittymisen ja työtehtävien vaativuustasojen muutosten kautta. Olisi myös tärkeää tutkia ammattikorkeakoulujen koulutusaloja vielä syvällisemmin nimenomaan ylempien tutkintojen suorittaneiden työmarkkina-aseman näkökulmasta, koska aloilla on omat historiansa, kulttuurinsa ja työmarkkinansa. Lisäksi tulisi tutkia eri korkeakoulusektoreiden tutkinnon suorittaneiden tosiasiallisia työmarkkina-asemia ja kilpailukykyä tarkkoja sijoittumistietoja vertailemalla. Avainkysymykseksi jää, vastaako YAMK-tutkinto valmistuneiden toiveisiin ja avaako se heille pääsyn haluttuihin työtehtäviin ja asemiin työmarkkinoilla.

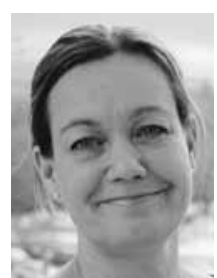

RISTIINA OJALA

$\mathrm{KT}$, tutkija

Kasvatustieteiden laitos

Turun yliopisto

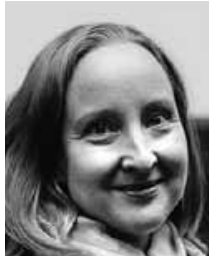

IPUKKA ISOPAHKALA-BOURET

$K$, apulaisprofessori

Turun yliopisto

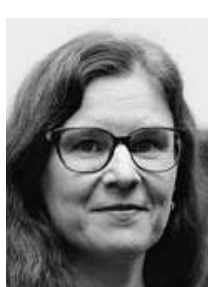

INA HALTIA

$\mathrm{KT}$, tutkijatohtori

urun yliopisto

'2000-luvulla useille tutkimuksille on tyypillistä alle 50 prosentin suuruiset vastausprosentit (Rasanen \& Sarpila 2013). Siitä huolimatta artikkelissa kyselyihin vastanneiden joukko edustaa relevanttia asiantuntemusta tutkittavasta IImiosta. Tutkimuksessa katoanalyysia ei ole kuitenkaan voitu tehda perinteisesti vertaamal a vastanneiden taustamuuttujia ei-vastanneisiin, eli tutkijoilla ei ole ollut tietoa siitä, miten vastaajaksi kutsuttujen joukko oli jakautunut. Tästä syystä tutkimuksessa on tehty mahdollisimman tarkkaa sisällöllisen edustavuuden ja kattavuuden analyysia, eli on tutkittu keitä vastaajat ovat ja minkalaista kokemusmaailmaa he edustavat suhteessa tutkittuun ilmiöön: onko se tutkittavan aiheen näkökulmasta kattava vai jollain tavalla tietynlaisen ryhmän kokemuksia painottava? Jälkikäteisellä aineiston laadun analyysilla on pyritty selvittämään, millaisella tavalla aineisto on mahdollisesti systemaattisesti valikoitunut. Tällöin kyse on ennemminkin aineiston sisallollisen kattavuuden analyysistä, mikä on ollut siitäkin syystä mahdollista, että tutkittavasta aiheesta tutkijalla on ollut jo suhteellise paljon etukäteistietoa. (Ronkainen 2008, 72-76.) Aineiston laadun maarittelevat erityisesti vastaajien osallistumisaktiivisuus, valikoituneisuus sekä vastausten rehellisyys ja täydellisyys. Vastausten määrä ei siten valttamatta vaikuta aineiston luotettavuuteen, vaan pikemminkin otoksen tasavertainen peittäyyys kaikista YAMK-tutkinnon suorittaneista (Miettinen \& Vehkalahti 2013). Verkkokyselytutkimuksella saadaan yleensä kattava peitto hyvin määritellyistä kohderyhmistä, johon on tässäkin tutkimuksessa pyritty rajaamalla kohderyhmä selkeästi tietyn ajanjakson aikana kaikkiin vakinaisen YAMK-tutkinnon suorittaneisiin ja joita vasta olikin tutkinnon uutuudesta johtuen suhteellisen vähän (Dillman. Smyth \& Christian 2009, 44).

LÄHTEET

Arene (2016). Ammattikorkeakoulujen maisterikoulutus osaamisen uudistajana ja kansallisena koulutusinnovaationa. Ammattikorkeakoulujen rehtorineuvoston Arenen ry:n selvitys

YAMKtutkintojen rakenteellisesta kehittämisesta. Ammattikorkeakoulujen rehtorineuvosto Arene ry. http://arene.fi (25.4.2018).

Arene (2018). Arenen lausunto ammattikorkeakoululain muuttamisesta 31.8.2018. OKM/35/010/2018. http://www.arene.fi/wp-content/uploads/ Lausunnot/2018/OKM Lausunto\%20amklain\%20 muuttamisesta_2018_08_31.pdf (14.11.2018).

Becker, G. S. (1962). Investment in Human Capita: Theoretical Analysis. Journal of Political Economy 70 (5), 9-49.
${ }^{2}$ Arcada - AMK, Humanistinen AMK, Hämeen AMK, Kajaanin AMK, Kemi-Tornion AMK, Centria AMK, Kymenlaakson AMK, Lahden AMK, Laurea-AMK, Metropolia AMK, Mikkelin AMK, Oulun seudun AMK, Pohjois-Karjalan AMK, Rovaniemen AMK, Saimaan AMK, Satakunnan AMK, SavoniaAMK, Seinäjoen AMK, Tampereen AMK ja Vaasan AMK. ${ }^{3}$ Luonnontieteiden ala on yhdistetty yhteiskuntatieteiden, liiketalouden ja hallinnon alaan sekä humanistinen ja kasvatusala kulttuurialaan aineistojen pienuuden vuoksi. Koulutusaloista puhutaan tekstissä lyhyillä nimillä: kulttuuriala, liiketalouden ala, luonnonvara-ala, matkailu- ja ravitsemisala, sosiaali- ja terveysala sekä tekniikan ala.

${ }^{4}$ Khiin neliö -testi on herkkä otoskoolle. Suurella otoskoolla (yli 500) se antaa helposti signaalin mallin huonosta sopivuudesta aineistoon, eli suurten aineistojen yhteydessä testi saa lähes aina suuria arvoja, jolloin malli tulisi hylätä. (Bentler \& Bonett 1980.) Khiin neliö -testin p-arvon tulisi olla ei-tilastollisesti merkitserä, mutta isoissa aineistoissa näin on harvoin, jolloin on suositeltava käyttää myös muita mallin yhteensopivusmittoja (Byrne 2012). Artikkelissa CFA-mallin sopivuuden testaamiseen käytettiin Khiin nelï -testin lisäksi seuraavia yhteensopivuusmittoja: Comparative Fit Index (CFI), Tucker- ewis Index (TL), Root Mean Square Error of Approximation (RMSEA) ja Standardized Root Mean Square Residual (SRMR). CFI ja TLl osoittavat, miten paljon paremmin malli sopil aineistoon rippumattoman mallin verrattuna (Tucker \& Lewis 1973). Sopivan mallin ja hyvän mallin sopivuden raja-arvona pidetä̈n arvoa lähellä tai yli 95 (Hu \& Bentler 1999). RMSEA testa mallin yleistä riittävyyttza vertaamalla estimoitua mallia täydellisen malliin (Metsämuuronen 2009, 696). Kun malli on sopivuudeltan hyvä, RMSEAn arvo tulee olla lähellä 06. SRMR on standardoitujen jä̈̈nnösten keskiarvo havaitun ja ennustetun kovarianssimatriisin välillä. SRMR kertoo mallin sopivan hyvin aineistoon, mikall sen avo on alle. 08 (Hu \& Benter 1999)

${ }^{5}$ Mallin sopivuus: $\mathrm{N}=1274: \times 2=63.949, \mathrm{df}=17 \mathrm{p}=$ .000 $\mathrm{CFI}=976, \mathrm{TL}=961, \mathrm{RMSEA}=047, \mathrm{SRMR}=038$

Bentler, P. M. \& Bonett D. G. (1980). Significance tests and Psychological Bulletin 88 (3), 588-606.

Bills, D. (2004). Sociology of Education and Work. Malden: Blackwell Publishing

Brown, D. (2001). The Social Sources of Educational Credentialism: Status Cultures, Labor Markets, and Organizations. Sociology of Education 74, 19-34.

Brown, P., Hesketh, A. \& Williams, S. (2003). Employability in a Knowledge-Driven Economy. Journal of Education and Work 16 (2), 107-12

Byrne, B. M. (2012). Structural Equation Modeling with Mplus. Basic Concepts, Applications, and Programming. New Tork: Routledge. 
Collins, R. (1979). The Credential Society: An Historical Sociology of Education and Stratification. New York: Academic Press.

Dillman, D. A., Smyth, J. D. \& Christian, L. M. (2009). Internet, Mail and Mixed-Mode Surveys. The Tailored Design
Method. Third edition. New Jersey: John Wiley \& Sons.

Galli, L. \& Ahola, S. (2010). Elinikäiset oppijat

lähikuvassa. Kokemuksia ja näkemyksiä ylemmistä ammattikorkeakoulututkinnoista. Koulutussosiologian tutkimuskeskuksen raportti 76. Turun yliopisto.

Herranen, J. (2003). Ammattikorkeakoulut diskursiivisena tilana. Järjestystä, konflikteja ja kaaosta. Joensuun yliopiston kasvatustieteellisiä julkaisuja nro 85 . Joensuun yliopisto.

Hu, L.-T. \& Bentler, P. M. (1999). Cutoff criteria for fit indexes in covariance structure analysis: Conventional criteria versus new alternatives. Structural Equation Modeling 6, 1-55.

Isopahkala-Bouret, U. (2014). 'It's considered a second class thing.' The differences in status between traditional and newly established higher education credentials. Studies in Higher education. 40 (7), $1291-1306$.

Isopahkala-Bouret, U., Rantanen, T., Raij., K. \& Järveläinen, E. (2011). European Qualifications Framework and the comparison of academically-oriented and professionallyoriented master's degrees. Europen Joun

Isopahkala-Bouret, U. (2018). Stratification through a Binary Degree Structure in Finnish Higher Education. In Bloch, R., Mitterle, A., Paradeise, C. \& Peter, T. (eds.) Universities and the Production of Elites: Discourses, Policies, and Strategies of Excellence and Stratification in Higher Education. London: Palgrave Macmillan, 83-101.

Kirjalainen, E. (2010). Viisi vuotta valmistumisesta ammattikorkeakoulusta valmistuneiden urakehitys. Uraseuranta vuonna 2003 valmistuneille. Selvitys seitsemän ammattikorkeakoulun yhteisistä tuloksista. Jyväskylän ammattikorkeakoulu.

L 2015/817. Laki sosiaalihuollon ammattihenkilöistä. Finlex. http://finlex.fi (10.10.2018).

Metsämuuronen, J. (2009). Tutkimuksen tekemisen perusteet ihmistieteissä. Tutkijalaitos. Internationa Methelp Oy. Helsinki.

Miettinen, J. \& Vehkalahti, K. (2013). Verkkokyselytutkimusten otosten valinta. Teoksessa Laaksonen, S.-M., Matikainen, J. \& Tikka, M. (toim.) Otteita verkosta. Verkon ja sosiaalisen median tutkimusmenetelmät. Tampere: Vastapaino, 84-104.

Mäki, K., Vanhanen-Nuutinen, L. \& Kotila, H. (toim.) (2017) AMK-maisteri - Työelämän moniosaja. Haaga-Helian julkaisut.

Naumanen, P. (2002). Koulutuksella kilpailukykyä.

Koulutuksen yhteys miesten ja naisten työllisyyteen ja gian tutkimuskeskuksen raportti 57. Turun yliopisto.
Neuvonen-Rauhala, M.-L. (2009). Työelämälähtöisyyden maarittaminen ja kayttaminen ammattikorkeakoulun jotkotutkintokokellussa. Jyvaskyla Studies in Education, Psychology and Social Research 367. Jyväskylän yliopisto. OECD (2017). Education at a Glance 2017: OECD Indicators. Paris: OECD Publishing. http://www.oecd.org/edu/ education-at-a-glance-19991487.htm (7.5.2018).

Ojala, K. (2017). Ylemmät ammattikorkeakoulututkinnot työmarkkinoilla ja korkeakoulujärjestelmässä. Väitöskirja. Kasvatustieteiden laitos. Turun yliopiston julkaisuja. Sarja C, osa 437

Ojala, K. \& Ahola, S. (2008). Ylemmät ammattikorkeakoulututkinnot: Kokeilusta kokemuksiin. Koulutussosiologian tutkimuskeskuksen raportti 71. Turun yliopisto.

Ojala, K. \& Isopahkala-Bouret, U. (2015). Ylemmän ammattikorkeakoulututkinnon ja maisterin tutkinnon suorittaneet työmarkkinoilla - tutkintojen statuserot, työkokemus ja työtehtävien eriytyminen kilpailuasetelman määrittäjinä. Teoksessa Aittola, H. \& Ursin, J. (toim.) Eriarvoistuva korkeakoulutus? Artikkelikokoelma Korkeakoulututkimuksen XII kansallisesta symposiumista 19. -20.8.2014. Jyväskylän yliopisto. Koulutuksen tutkimuslaitos.

OKM (2011). Selvitys ylempien ammattikorkeakoulututkintojen asemasta työelämässä ja uudistuksen vaikutuksesta koulutusjärjestelmään ja työelämään. https://docplayer.fi/679248-Selvitysylempien-ammattikorkeakoulu-tutkintojenasemasta-tyoelamassa-ja-uudistuksen-vaikutuksestatext (8.11.2018)

OKM (2017). Korkeakoulutus ja tutkimus 2030-luvile. Taustamuistio korkeakoulutuksen ja tutkimuksen 2030 visiotyölle. http://minedu.fi/korkeakoulutuksen-jatutkimuksen-visio-2030 (11.4.2018).

OPM (2009). Korkeakoulut 2009. Yliopistot ja ammattikorkeakoulut korkeakoulupolitiikan toteuttajina. Opetusministeriön julkaisuja 2009:49

Panhelainen, M. \& Varmola, T. (2017). Ylemmät AMKtutkinnot - Työelämän ja korkeakoulupolitiikan innovaatio. Teoksessa Mäki, K., Vanhanen-Nuutinen, L. \& Kotila, H. (toim.) AMK-maisteri - Työelämän moniosaaja. Haaga-Helian julkaisut, 15-27.

Pratt, J., Kekäle, T., Maassen, P., Papp, I., Perellon, J. \& Uitti, M. (2004). Equal, but Different. An Evaluation of the Postgraduate Polytechnic Experiment in Finland. Final Report. Finish Higher Education Evaluation Council. https://docplayer.fi/679248-Selvitys-ylempienammattikorkeakoulu-tutkintojen-asemasta-tyoelamassaja-uudistuksen-vaikutuksesta-koulutusjarjestelmaan-jatyoelamaan.html\#show_full_text (8.11.2018).

Rantanen, T., Isopahkala-Bouret, U., Raii, K. \& Järveläinen, E. (2010). Ylemmät ammattikorkeakoulututkinnot, yliopistolliset maisterin tutkinnot ja eurooppalainen
tutkintojen viitekehys, Aikuiskasvatus 30 (4), 267-279.
Rantanen, T. \& Järveläinen, E. (2010). Ylempi AMKtutkinto tyoelämän kehittamistutkintona. Teoksessa Rantanen, T. \& Isopahkala-Bouret, U. (toim.) Näkökulmia ylemmän ammattikorkeakoulututkinnon tuottamaan osaamiseen sosiaali- ja terveysalalla. Vantaa: Laurea ammattikorkeakoulu, 129-150. Ronkainen, S. (2008). Otanta, edustavuus ja kadon analyys
Teoksessa S. Ronkainen \& A. Karjalainen (toim.) Sähköä kyselyyn! Web-kysely tutkimuksessa ja tiedonkeruussa. Lapin yliopiston menetelmätieteiden laitoksen tutkimuksia 1. Lapin yliopisto, 70-76

Räsänen, P. \& Sarpila, O. (2013). Internet-lomake vai ei? Verkkokyselylomake postikyselyitä täydentävänä tiedonkeruun menetelmänä. Laaksonen, S.-M., Matikainen, J. \& Tikka, M. (toim.) Otteita verkosta. Verkon ja sosiaalisen median tutkimusmenetelmät. Tampere: Vastapaino, 68-83.

Sainio, J., Carver, E. \& Kangas, T. (2017). Eväitä hyvän työuran rakentamiseen. Aarresaari-verkoston maisteriseuranta 2016. Aarresaari - Yliopistojen työelämä- ja urapalveluiden verkosto.

Schultz, T. W. (1961). Investment in human capital. The American Economic Review 51 (1), 1-17.

Spence, M. (1973). Job market signaling. The Quarterly Journal of Economics 87 (3), 355-374.

Stenström, M. L., Laine, K. \& Valkonen, S. (2005). Ammattikorkeakoulut vällänä työelämään. Hallinnon ja kaupan, tekniikan ja liikenteen sekä sosiaali- ja erveysaloilta valmistuneiden työelämään sijoittuminen a työelämätaidot. Koulutuksen tutkimuslaitos, tutkimusselosteita 45. Jyväskylän yliopisto.
Suomen virallinen tilasto SVT (2018). Ylempään ammattikorkeakoulututkintoon johtava koulutus Isaàntyi edelleen. Ammattikorkeakoulukoulutus. Helsinki: Tilastokeskus. http://www.stat.fi/til/akop/2017/ akop_2017_2018-04-18_tie_001_fi.html (7.5.2018).

Tomlinson, M. (2008). 'The degree is not enough': Students' perceptions of the role of higher education credentials for graduate work and employability. British Journal of Sociology of Education 29 (1), 49-61.

Tucker, L. R. \& Lewis, C. (1973). A reliability coefficient for maximum likelihood factor analysis. Psychometrika 38, 1-10.

Tuominen, V. (2013). Maistereiden työllistyyyys. ItäSuomen yliopiston julkaisuja 57. Yhteiskuntatieteiden ja
kauppatieteiden tiedekunta.

Varamäki, E., Heikkilä, T. \& Lautamaja, M. (2011). Nuorten, aikuisten sekä ylemmän tutkinnon suorittaneiden sijoittuminen työelämään - seurantatutkimus Seinäjoen ammattikorkeakoulusta v. 2006-2008 valmistuneille. Seinäjoen ammattikorkeakoulun julkaisusarja B. Seinäjoen ammattikorkeakoulu.

Vinamäki, L. \& Pohjola, A. (2016). Tutkimus sosionomi (ylempi AMK) tutkinnon suorittaneiden koulutus- ja työmarkkinaasemasta.

Vipunen - Opetushallituksen tilastopalvelu (2018). (9.1.2018).

Vuorinen-Lampila, P. (2016). Gender segregation in the employment of higher education graduates. Journal of Education and Work 29 (3), 284-308.

Vuorinen, P. \& Valkonen, S. (2007). Korkeakoulutuksesta työelämään. Työhönsijoittuminen ja työelämävalmiudet kaupan ja tekniikan alalla. Koulutuksen tutkimuslaitos, tutkimusselosteita 37. Jyväskylän yliopisto.

LIITE 1

Valmistuneiden työmarkkina-asemaa määrittäviä tekijöitä käsittelevät faktorit ja niistä muodostetut summamuuttujat.

\begin{tabular}{|c|c|}
\hline Summamuuttujat & $\begin{array}{l}\text { Summamuuttujaan sisältyvät / } \\
\text { faktoreilla latautuneet väittämät }\end{array}$ \\
\hline F1 Tutkinnon tuottama kilpailukyky ( $\alpha=.77$ ) & $\begin{array}{l}\text { A1) YAMK-tutkintoa arvostetaan työmarkkinoilla maisterin } \\
\text { tutkintoa vähemmän* (.78) } \\
\text { A22) Työnhakutilanteessa YAMK-tutkinnon suorittaneet } \\
\text { häviävät maistereille* (.76) } \\
\text { A3) YAMK-tutkinnon suorittaneilla on maistereita } \\
\text { paremmat uralla etenemisen mahdollisuudet (.69) } \\
\text { A44 YAMKK-tutkinnon suorittaneet sijoittuvat paremmin } \\
\text { palkattuihin työtehtävioin kuin maisterit (.69) } \\
\text { A5) Työnantajat tuntevat YAMK-tutkinnon maisterin } \\
\text { tutkintoa huonommin* (.61) }\end{array}$ \\
\hline F2 Tutkinnon tuottama osaaminen $(\alpha=.66)$ & $\begin{array}{l}\text { B1) YAMK-tutkinnon suorittaneiden työelämäosaaminen } \\
\text { on maisterin tutkinnon suorittaneita vahuempi (.74) } \\
\text { B2) YAMK-tutkinto tuottaa spesifisempää osaamista kuin } \\
\text { maisterin tutkinto (.71) } \\
\text { B3) YAMK-tutkinto tuottaa samantasoista osaamista kuin } \\
\text { maisterin tutkinto (.70) } \\
\text { B4) YAMK-tutkinnon suorittaneilla on mahdollisuus toimia } \\
\text { maisterien kanssa samantasoisissa työtehtävissä (.56) }\end{array}$ \\
\hline
\end{tabular}

*väittämä käsitelty käänteisenä 